\title{
STITCHING HISTORY: FILIPINA GARMENT WORKERS IN WINNIPEG
}

\author{
by \\ Shirley Camia \\ BA, York University, 2002 \\ A Major Research Paper \\ presented to Ryerson University \\ in partial fulfillment of the requirements for the degree of \\ Master of Arts \\ in the program of \\ Immigration and Settlement Studies
}

Toronto, Ontario, Canada, 2012

(C) Shirley Camia, 2012 


\section{Author's Declaration}

I hereby declare that I am the sole author of this Major Research Paper.

This is a true copy of the MRP, including any required final revisions, as accepted by my examiners.

I authorize Ryerson University to lend this MRP to other institutions or individuals for the purpose of scholarly research.

I further authorize Ryerson University to reproduce this MRP by photocopying or by other means, in total or in part, at the request of other institutions or individuals for the purpose of scholarly research.

I understand that my MRP may be made electronically available to the public. 


\title{
STITCHING HISTORY: FILIPINA GARMENT WORKERS IN WINNIPEG
}

\author{
(C) Shirley Camia \\ Master of Arts, 2012 \\ Immigration and Settlement Studies \\ Ryerson University
}

\begin{abstract}
This research project examines the working experiences of Filipino women who moved to Winnipeg in the 1960s and 1970s to become garment workers. Findings are drawn from oral history interviews with Filipina garment workers who arrived between 1968 and 1974. The participants, who have become pioneers in Winnipeg's Filipino community, will be a part of Canadian history that has, so far, been poorly documented. This paper will also examine the garment industry in Winnipeg prior to the arrival of the first Filipina garment workers, as well as the push and pull factors which led to their migration from the Philippines.
\end{abstract}

\section{Key words:}

Filipino; women; garment industry; immigration; work; Philippines; Winnipeg 


\section{Acknowledgements}

I want to thank my MRP supervisor, Dr. Sedef Arat-Koc, for her invaluable insight and advice, and for guiding this paper to completion. I also want to thank Dr. Myer Siemiatycki for providing a critical eye as the second reader.

I also want to acknowledge the support of both Darlyne Bautista and Perla Javate, who graciously helped me find participants willing to take part in my study.

Lastly, I am grateful to the generous women who shared their life experiences with me, and who offered me merienda as they revealed their pasts with candour, humour and warmth. This paper is dedicated to them. 


\section{Table of Contents}

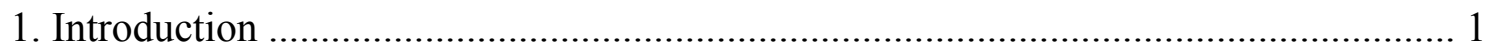

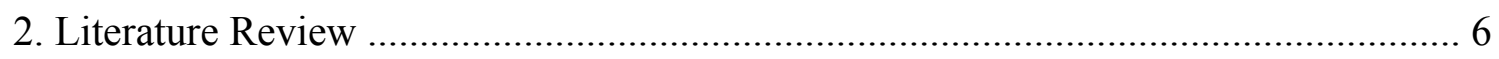

2.1. Filipina Garment Workers in Winnipeg ................................................ 7

2.2. Garment Workers from other Racialized Groups ................................... 12

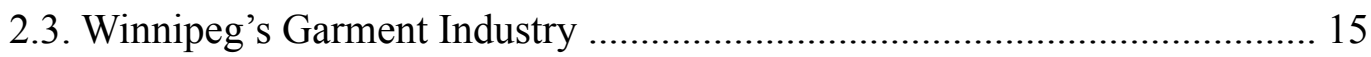

2.4. Theoretical Framework ................................................................ 18

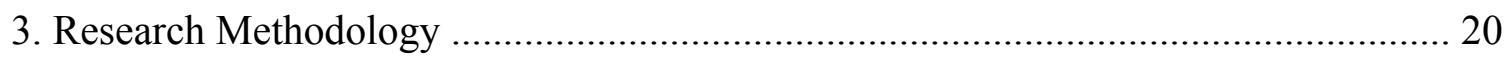

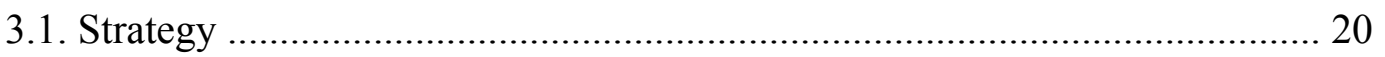

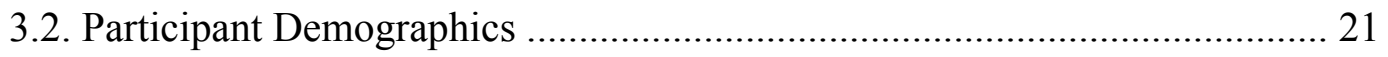

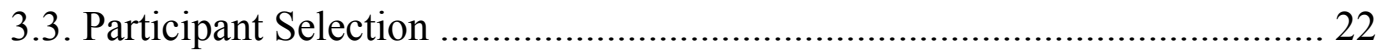

3.4. Data Collection Tools and Process ......................................................... 23

3.5. Ethical Considerations ..................................................................... 23

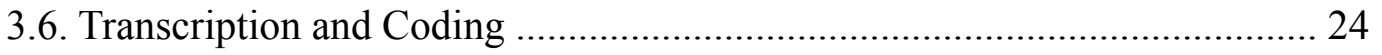

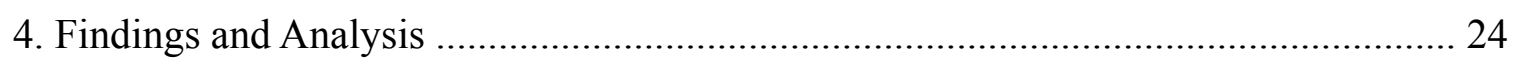

4.1. The Recruitment Process ............................................................................ 24

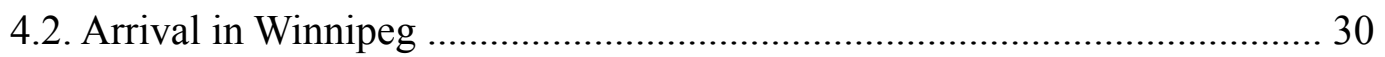

4.3. Work ............................................................................................. 33

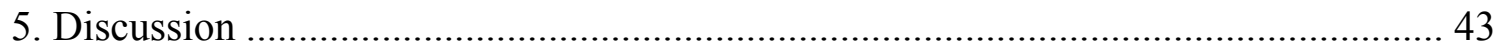

5.1. The Fact that their Conditions in the Same Sector in the Philippines were

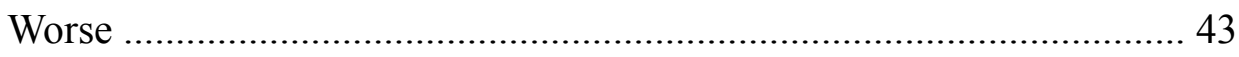

5.2. Low Expectations and Job Opportunities ............................................. 44 
5.3. The Sense of Pride in Sending Money and Improving Conditions for

Family at Home ................................................................... 47

5.4. Limited Social and Political Exposure .................................................. 48

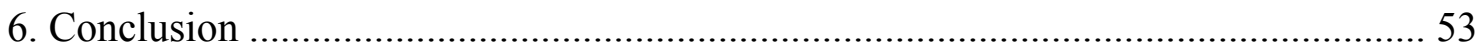

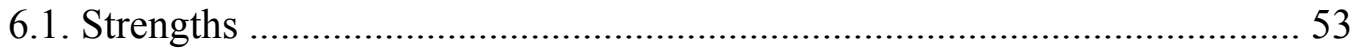

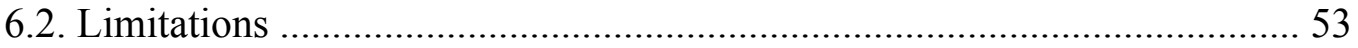

6.3. Recommendations for Further Research ............................................... 56

7. List of Appendices

Appendix A: Telephone Script …........................................................... 59

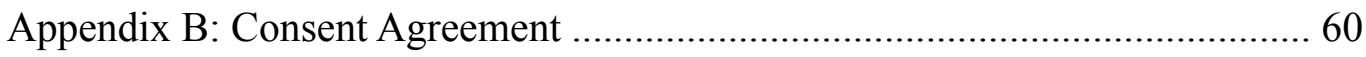

Appendix C: Interview Questions ........................................................... 63

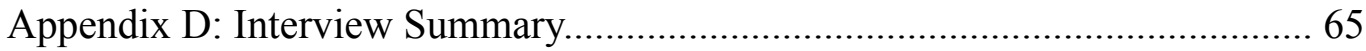

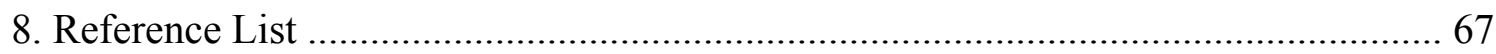




\section{Foreword}

The reason behind my interest in the topic of Filipina garment workers in Winnipeg is a personal one: my mother and a number of my aunts were all sewing machine operator recruits from the Philippines. In coming to Canada to improve their livelihoods, they subsequently improved mine, and that of future generations of Filipino-Canadians who were given opportunities to succeed because of their efforts. Therefore, their past has shaped my present, and with it, a renewed interest in their collective history. Previous conversations with relatives have led to the emergence of only a handful of stories. However, I wanted to study this topic in greater detail, to fully capture some of their experiences. In particular, I wanted to learn about and understand their day-to-day challenges, as they unknowingly helped pave the way for the growth of Winnipeg's Filipino community.

The research I undertook was also in part a response to the dearth of literature on this topic. I was surprised, and disappointed, with the lack of resources that were available. Most of the existing literature discussed Filipinos as nannies and domestics, under the context of Canada's Live-In Caregiver Program. The lack of research firmly cemented my plans to generate my own, by speaking directly to Filipina garment workers and studying their experiences firsthand. While speaking to the women gave me their perspectives on their working lives in Canada, their oral histories did not provide the whole story. By writing this paper, I hoped to fill in the rest of contextual pieces that were missing from their narratives. 


\section{Terminology}

In this paper, the term garment worker will be used to describe the women who were employed in the garment industry largely as sewing machine operators. They were single, strong, skilled and willing to work for low wages. The term is created in part from the description of the first Filipina garment recruits who moved to Winnipeg, which is outlined in one of the sources (Lepp, Millar \& Roberts 1987). The time frame being examined in the paper is also very specific: it will only focus on the first few waves of Filipino women who migrated to Winnipeg from the Philippines, from the arrival of the first group in 1968 to the mid-1970s. The term Filipina will also be used, which, in the Filipino language of Tagalog, is used to describe a woman of Philippine descent. 


\section{Section 1: Introduction}

In a nation built largely by immigrants, the gains of migrants are met with losses; with a new land comes a departure from the old, along with the arrival of new opportunities and the promise of a better life. For many Filipino women, this tradeoff frequently results in the separation from a rich network of loved ones, and all that is familiar, in exchange for an opportunity to find steady employment and an income that is used to help support their relatives in the Philippines. The necessity to help one's family by leaving her homeland, due to an economic climate that has resulted in poor employment opportunities, has for decades, driven Filipino women to leave the Philippines and move to Canada. Many of these women landed in Winnipeg in the 1960s and 1970s. They supplied a cheap labour force to Manitoba's textile factories, in poorly paid positions that most Canadians had no desire to fill.

In this paper, the experiences of Filipina garment workers who arrived in Canada during the aforementioned time period will be investigated, within the historical context of Winnipeg's labour market. The primary question that will be addressed is as follows: How do Filipino women who worked in Winnipeg's garment industry during the 1960s and 1970s perceive their working conditions and experiences as garment workers? Secondary questions include: How fairly do they think they were treated by their employers and colleagues? What instances of unjust treatment or racism did they experience? How did they react to any negative experiences? Additional questions are: Why did they leave the Philippines in the first place? What were their initial living conditions when they arrived in Winnipeg? 
In order to understand the working experiences of the women in these factories, this study will use personal interviews with Filipina women in the garment trade. To contextualize the findings of the interviews, select research from a number of sources, including books (Gannage 1986; Frager \& Patrias 2005; Frager 1992), a Master's thesis (Buduhan 1972), a report (Khatun 2005) and even a museum exhibit ("From Manila to Manitoba") will be analyzed in an attempt to answer the aforementioned research questions. However, not all the resources previously mentioned deal directly with the experiences of Filipina garment workers in Winnipeg. There is a gap in literature on this very topic, which may, in part, be attributed to their relatively recent arrival. To supplement the dearth in sources dealing directly with this specific group of women, literature discussing the experiences of garment workers from other racialized groups, as well as Winnipeg's garment industry in general, will be used in this paper. In essence, a number of areas will be looked at as the research findings are explored, specifically, the historical context of labour and immigration in Winnipeg, the need for cheap labour and the overall issues of workforce discrimination based on gender, ethnicity and class.

As the main focus of this study is to examine the perceived working experiences of Filipina garment workers, in an effort to build on the limited amount of pre-existing resources, interviews were conducted with a number of such women who arrived in Winnipeg between 1968 and 1974. The quotes from the in-depth, personal interviews will offer a glimpse into the lives of Filipino women who migrated to Winnipeg, in the hopes of improving their lives and the lives of their loved ones, while inadvertently becoming the roots of one of Winnipeg's largest ethnic communities that presently stands at nearly 60,000 people (Lett 2012). 
Before continuing further, it is important to provide a brief understanding as to why Winnipeg became the site of migration for Filipina garment workers in the 1960s and 1970s. Two perspectives will be examined: the perspective of the factory owners and the Canadian government, as well as the perspective of the Filipino women.

The history of Manitoba's garment industry, as chronicled by one of the sources (Lepp, Millar \& Roberts 1987), suggests that the city's garment sector was on the verge of collapse in the 1960s. Factors leading to its demise included the reluctance of Canadians to perform such hard work for low wages and a competitive market (Lepp, Millar \& Roberts, 1987, p. 157). Therefore, in a bid to save the province's flagging industry, "a substantive proportion of labour would be directly recruited overseas" (Lepp, Millar \& Roberts, 1987, p. 157), through an initiative supported by Immigration Canada. As a result, women from the Philippines were directly scouted and recruited (Lepp, Millar \& Roberts, 1987, p. 158) in the late 1960s, ushering in the first of many waves of Filipina garment workers that headed to Winnipeg.

This recruitment is part of the federal government's long history of using immigration to boost the Canadian economy and support Canada's proliferation as a white setter/white dominant nation. Historically, the country's immigration policies stated that British descendants were at the "top of the list," in terms of those who were considered ideal citizens, and those who were welcomed in the country (Kelley \& Trebilcock, 1998, p. 442). For racialized groups, it was a different story: from the implementation of a Chinese head tax (Kelley \& Trebilcock, 1998, pp. 120-121), to the continuous journey regulation, which restricted people, particularly from India, from entry into Canada (Kelley \& Trebilcock, 1998, p. 148) and the internment and so-called repatriation of those of Japanese descent, including many of whom were born in the country 
(Kelley \& Trebilcock, 1998, pp. 293-305), Canada has had a long history of restricting the movement and freedoms of racialized groups.

Canadian immigration policies are also linked to the labour market, where "race has been and continues to be a major factor in determining access to economic opportunity" (Galabuzi, 2006, p. 7). According to theorist Himani Bannerji:

From the days of indenture to the present... decisions about who should come into Canada to do what work, definitions of skill and accreditation, licensing and certification, have been influenced by "race" and "ethnicity." (1998, p. 144)

Bannerji's assertion effectively summarizes the actions of the Canadian government. For example, while people of Chinese descent were used to help construct one of the most significant markers of nation building, the Canadian Pacific Railway, or CPR (Kelley \& Trebilcock, 1998, p. 94), a head tax, as mentioned, was still introduced to control the Chinese population. However, the implementation of the head tax was done strategically: it was introduced at a time when the construction of the CPR was complete and "there was no longer a pressing demand for their (Asian) labour" (Kelley \& Trebilcock, 1998, p. 15).

Bannerji's critique can also be applied to the Filipina garment workers who arrived in Canada. They were allowed into the country, but, as mentioned, largely as a source of cheap labour to boost Canadian business, by filling jobs that were largely undesired by most Canadians. Like many newcomers, their knowledge and education were discredited due to discrimination on the basis of their racialized background and country of origin. Yet for various reasons, such as the opportunity to earn Canadian dollars and support families back home, many decided to stay. 
The women who were interviewed for this research paper are no exception: they came from what they described as poor, working-class households in the Philippines, at times with only one parent working to support the family. Their parents were usually farmers or employed in the garment industry themselves, and often ill-paid, which necessitated the women's eventual need to work.

As the women entered the workforce in the Philippines, a simultaneous economic shift occurred: workers began to be perceived as viable exports that could be used to sustain the national economy. This perspective was actively promoted by the government, and still pervades Philippine society to this day (Bejar, 2006, p. 16):

Philippine governments over the last four decades actively encouraged the marketing of Filipina workers. Due to the highly competitive market of labour export, where the supply is higher than the demand, the Philippines Overseas Employment Administration (POEA) actively marketed Filipinas as unique and desirable workers for niche markets. Ferdinand Marcos, whose presidency and martial law spanned three decades, was the first to promote Philippine migration. (Bejar, 2006, pp. 16-17)

The reasons listed above provided complementary elements for migration to Canada: the pull factors of the promise of secure employment and potential economic success in Winnipeg (in spite of the exploitation by factory owners and the Canadian government), as well as the push factors of economic necessity and the Philippine government's promotion of migration as a solution to offset that need, would eventually lead to the influx of Filipino women in Manitoba during the 1960s and 1970s to work in the garment trade. 


\section{Chapter 2: Literature Review}

This study looks solely at the working experiences of the Filipina garment workers in question, who, from the late 1960s onward, helped to firmly establish one of the largest ethnocultural groups that populate Winnipeg. Yet despite the contributions of these women, there seem to have been few efforts made to document their experiences. Often, literature looking into their experiences lacks specific focus and detail. They discuss Filipino women as part of women from other racialized groups, or they mention them in relation to the migration experiences of Filipino-Canadians in general. Therefore, the topic becomes even more necessary to investigate, as the roots of Winnipeg's Filipino community are intertwined with the arrival of Filipina garment workers, and this topic appears to lack any in-depth documentation. The dearth of knowledge may be reflective of the relatively recent history of Filipino migration to Canada (Bejar, 2006, p. 10), and specifically, Winnipeg. It means, however, that the investigation must consider a number of other resources that address similar topics, yet do not directly speak to the experiences of Filipino women, such as the experiences of other groups of garment workers that came to Canada.

This literature review will attempt to discuss significant themes surrounding the core question of the working experiences of Filipina garment workers in the 1960s and 1970s. There is existing research that discusses, to varying degrees, the experiences of Filipina garment workers (Buduhan 1972; Dalayoan 2012; "From Manila to Manitoba”) in Winnipeg. The resources on Filipina garment workers will be supplemented with literature detailing the experiences of garment workers from other racialized groups (Frager 1992; Frager \& Patrias 2005; Gannage 1986; Giesbrecht 2010): the women all worked in the same profession and 
therefore, may have had similar experiences. Finally, research looking at Winnipeg's garment industry on the whole will be examined (Lepp, Millar \& Roberts 1987; Khatun 2005), with a particular emphasis on how migrants such as Filipinos were used to fill the need for workers. By examining the aforementioned resources, the need for further research in this field of study will be revealed.

\subsection{Filipina Garment Workers in Winnipeg}

Literature in this area is extremely limited, with only one resource examining in full detail the settlement experiences of the first batches of Filipina garment workers (Buduhan 1972). Two other resources (Dalayoan 2012; "From Manila to Manitoba") also contain information, albeit in varying degrees, on the working conditions and experiences of garment workers, as described by a number of such women themselves.

Cleto Buduhan's Master's thesis, An Urban Village: The Effect of Migration on the Filipino Garment Workers in a Canadian City, described the women's entire migration, from their lives in the Philippines, to the recruitment process, their settlement experiences and ultimately, their working experiences in the garment trade. Unlike the museum exhibit ("From Manila to Manitoba") and the documentary (Dalayoan 2012), which are two recently completed sources that look at the garment industry as an era in the past, Buduhan's work takes a different view. He completed his thesis in 1972, and in doing so, was able to describe the first migrant Filipina garment workers' experiences soon after they arrived in Winnipeg. He focused on the initial arrival period, from 1968 to 1972. Buduhan's work is comprehensive: as an anthropologist, he captured the minutiae of the migration process, and even included diary 
entries from one of the recruits. In addition, his interviews with the women captured the essence of their initial thoughts and sentiments upon arriving in Winnipeg.

Buduhan's findings showed that the workers in Winnipeg's garment industry did experience harsh treatment, including sexual harassment, due to their ethnicity, class and gender. Buduhan, who had worked briefly in a garment factory to fully understand the experiences of his fellow Filipino garment workers (1972, p. 20), witnessed a number of negative encounters, including the following:

1) A newly married worker told the foreman that she needed the service of the factory mechanic. Thereupon the foreman responded with "Why, is your husband no good already?"

2) A worker was hanging the finished coats. The foreman was passing by and cupped his palm on the worker's breast. (1972, p. 149)

Buduhan, who himself was Filipino, had been told by a foreman, "Go screw yourself. You know your country is too poor so you come here" $(1972$, p.149). Such working environments took their toll on the Filipino workers, with one saying that as a result of the conditions they faced, they could do nothing but cry (Buduhan, 1972, p. 153). One way to offset the physical and mental strain of the job was to seek solace from fellow Filipinos, by clustering into groups (Buduhan, 1972, p. 153). Buduhan said that the workers were afraid to protest because they feared "they will remove us" (1972, p. 152), although it was not made clear whether removal in this context meant removal from the company or the country.

As a former garment worker, Buduhan had direct experience and knowledge of the topic in question, which was reflected in his findings. His thesis is thus far the only source encountered which captured the Filipina garment workers' experiences in great detail. However, he only 
focused on the first batch of Filipina recruits; the Filipina women who came later may have had different recruitment and settlement experiences that may not have been included in Buduhan's findings.

The museum exhibit ("From Manila to Manitoba") and the documentary (Dalayoan 2012), therefore, in a sense, pick up the longer range view of the Filipina garment workers' history where Buduhan's thesis leaves off. The exhibit consisted of several panels chronicling the historical migration of Filipinos to Manitoba, which was similar to the narrative structure of the documentary. Both contained personal anecdotes, as well as images, from first and second generation Filipino-Canadians about how their lives unfolded as they settled in Winnipeg. Of most use to this paper are sections of both the museum exhibit and the documentary that featured information on garment workers that arrived in Winnipeg in the 1960s and 1970s.

The museum panels included first-hand accounts of the garment workers' experiences, a timeline of their migration, as well as photographs. Included in one of the panels is an interesting quote that explains how the Filipina recruits were viewed from a business standpoint. It was given by Graeme Haig, the former president of the Manitoba Chamber of Commerce:

For Manitoba to survive in the garment industry it needs good low cost labour and by low cost labour I don't mean poorly paid workers. I mean well skilled labour from overseas who are paid well for turning Canadian raw materials into clothing. ("From Manila to Manitoba")

The quote attempted to offset the idea that the Filipina garment workers were being exploited. The inference is such that the women, who were accustomed to earning low wages in the Philippines, would be earning good wages in Canada, especially when they converted their money to Philippine pesos. However, that did not mean that they were making good money 
according to Canadian standards. In addition, employers could attest that their clothes were made in Canada, but, as the Filipino women were recruited from overseas, that did not mean that they were providing good jobs to Canadians, nor did it mean that the women were treated fairly, just because the conditions and wages in the Philippines might have been worse than those in Canada. As well, the quote implied that the women were outsiders. Their only value was turning "Canadian" raw materials into clothing.

Another quote from a former member of provincial parliament, Jay Cowan, addressed the garment industry's history of exploiting its workers:

Without hesitation I can state that I believe that the garment industry owners find themselves in the position of not being able to hire local workers because of their own actions... (T)he facts are that many unemployed Manitobans who know the industry best do not want to work in it. ("From Manila to Manitoba")

Although not stated outright, what was implied by the quote were the challenging working conditions and the low pay associated with the garment industry, which, as Cowan mentioned, many Canadian-born workers would not tolerate.

Yet the exhibit suggested that Filipino women also refused to tolerate the inequities in the garment factories, by including images related to a strike. In one of the panels, two women, as well as a young child, wore placards saying, "Legal Strike, Local 286 ILGWU1." Accompanying the photo was a newspaper byline that read, "Salary differential based on sex bias, striking garment workers charge" (Wiley 1981). This panel is significant because it showed that Filipino women also felt that they were being treated unfairly and were strong enough to stand up for their rights. The museum exhibit is relevant to the study, addressing such issues as treatment and

\footnotetext{
${ }^{1}$ ILGWU is the International Ladies' Garment Workers' Union (Giesbrecht, 2010, p.5).
} 
discrimination. However, it lacked depth concerning the women's recruitment process and working experiences.

Like the exhibit, the documentary did not give much contextual information on the working experiences of Filipina garment workers in Winnipeg. Manila Road featured interview segments from one garment worker who came in 1968, during the first wave of their collective migration. Overall, the documentary was autobiographical, focusing on the filmmaker and his family, and the story of their migration from the Philippines to Winnipeg.

According to Fernando Dalayoan's interview with the one garment worker in his documentary, one major finding that emerged was the issue of loneliness. The garment worker briefly described her arrival in Winnipeg and being chosen by the factory for which she would work. She said that while she was very excited, she was also very lonely. The feeling of loneliness remained until she was able to sponsor her boyfriend from the Philippines. In this specific instance, Dalayoan's documentary demonstrated the significant emotional impact of the move to Winnipeg on the garment workers, which ultimately illustrated how dire the women's situations were in the Philippines if they chose to give up all that they knew in order to improve their lives. This anecdote was the only major point in the garment worker's interview that related to the study; she did not go further into describing any of her working conditions or experiences at the factory that hired her.

Ultimately, both the documentary and the exhibit provided vital information, researched from a number of credible sources, from the viewpoints of many Filipinos within the Canadian and Manitoban context. However, they did not focus solely on Filipina garment workers. Newspaper articles (i.e. Litta-Magnus 1969) may be able to assist in providing more information 
on the Filipinas' experiences, albeit without any of the depth necessary to truly capture the women's overall working lives.

\subsection{Garment Workers from other Racialized Groups}

A number of resources on garment workers from other racialized groups (Frager 1992;

Frager \& Patrias 2005; Gannage 1986; Giesbrecht 2010) discussed not only the unjust working conditions of the women involved, but also the efforts that were made to mobilize and fight for their rights. Three of those resources (Frager 1992; Frager \& Patrias 2005; Giesbrecht 2010) mainly discussed the experiences of Jewish garment workers in Toronto (Frager 1992; Frager \& Patrias 2005) and Manitoba (Giesbrecht 2010). Another book (Gannage 1986) discussed the experiences of Jewish garment workers, but also those of other racialized groups, including Portuguese and Italian workers. One limitation in all of these books, in terms of the focus of the study, is the time frame being examined: they all looked at the lives of immigrant garment workers before 1968, ranging from 1870 to 1945 . Also, the working conditions of Jewish, Portuguese and Italian women may have differed from those of Filipino women, not only in terms of ethno-cultural makeup, but factors such as the different cities in which they settled and the differing time periods in which they arrived. However, there may have also been similarities, and these mutual factors could potentially be used to describe the experiences of Filipina garment workers as well.

In Jodi Giesbrecht's article, Accommodating Resistance: Unionization, Gender, and Ethnicity in Winnipeg's Garment Industry, 1929-1945, she specifically talked about factors leading to the political resistance of Jewish women in Winnipeg, which included issues surrounding gender, class and ethnicity. Giesbrecht discussed the history of Winnipeg's garment 
industry, noting that the majority of its workers were not just women, but immigrants, namely Jewish, Polish and Ukrainian because their racialized backgrounds and immigrant status linked them to cheap labour. As Giesbrecht put it, "(t)he garment industry was one of the few spheres in which female immigrants could obtain employment in Winnipeg's discriminatory and paternalistic economy" (2010, p. 6). She also said that while Jewish factory owners employed other Jews, some factories did not, citing a proclivity to protests and resistance in a field otherwise already marred by exploitation. Giesbrecht stressed that the radicalism of Jews was "deeply entrenched in Jewish culture" (2010, p. 7), from ideas carried to North America from their countries of origin. However, in the Philippines during the 1960s and 1970s, the repressive regime of former President Ferdinand Marcos, along with his labour-export policies, did not initially lead to political resistance, but an exodus of Philippine citizens seeking employment abroad (Bejar, 2006, pp. 10-11). Therefore, while Giesbrecht's article discussed garment workers in Winnipeg factories, it cannot fully be applied to Filipino women.

Another resource (Gannage 1986) provided a look at garment workers and their organizing efforts. In her book, Double Day, Double Bind: Women Garment Workers, Charlene Gannage not only discussed the experiences of Jewish women, but women from other racialized backgrounds, including Portuguese and Italian. Unlike Giesbrecht's piece, Gannage's book looked at workers in Toronto; she focused all of her research on a specific garment shop in the city, detailing its history while situating it within the greater contexts of the clothing industry in Toronto, as well as Canada. Gannage's findings resulted from interviews conducted with a small sample of workers at Edna Manufacture within a two-year time period, from 1980 to 1982. In her results, she found rampant discrimination and the harsh treatment of workers at the factory; one 
of the interview participants said that the co-owner of Edna Manufacture, who was Jewish, did not like to hire non-Jews and females (1986, p. 108). However, Gannage's findings showed that the women were reticent in becoming members of the union to fight for their rights because of ethnicity and language barriers. She noted that the majority of union leaders were Jewish men who often spoke Yiddish to each other, which discouraged the women, many of whom already had trouble speaking in English, from getting involved (1986, p. 181). The double day, which entails women working for income and then returning home to complete gendered work such as cooking and childcare (1986, p. 53), also prevented women from acquiring English skills as their family commitments took precedence over their learning. One interviewee said that she was not free to go to school at night and therefore had to learn English on her own, which made it harder to become proficient (Gannage, 1986, p. 181). The barriers perpetuated the women's marginalized statuses: the lack of English ability, combined with their being marginalized, led to a lack of self-confidence, which then kept them in their place. Gannage also discussed how Jewish women, unlike non-Jewish women, were more comfortable participating in the union than other racialized groups because the union office was located in the same neighbourhood in which most of the Jewish workers lived, creating a sense of camaraderie and community (1986, p. 113).

Despite its detail and first-person experiences of several garment workers, Gannage's indepth study of one particular establishment may provide limitations to the generalizability of her results, in terms of the research topic. In addition, as the Filipina garment workers in question migrated to Canada as single women without children, the idea of the double day did not fully apply to their circumstances upon arrival. However, Gannage's findings of the differences in 
union participation among Jewish women and other racialized females in the garment industry is integral to the major research paper, providing insight into why some groups of women were more inclined to be politically active than others.

Like the previous two resources, Ruth Frager's Sweatshop Strife: Class, Ethnicity, and Gender in the Jewish Labour Movement of Toronto, 1900-1939, as well as Ruth Frager and Carmela Patrias' Discounted Labour: Women Workers in Canada, 1870-1939, argued that women from the most disadvantaged racialized groups were looked upon as cheap labour, facing discrimination in the workforce because of ethnicity, gender and class. Frager's work (1992) was different in that she also included prostitution and white collar professions along with manufacturing jobs. She also raised the issue of resistance and its limitations, citing differences in ethno-cultural background and class among the factors that hinder unity among all women who work. In Frager and Patrias' book (2005), they brought up the same issues of class, ethnicity and gender, but their work focused on Jewish women in Toronto. Like Giesbrecht's article and Gannage's study, for these two books, the issue emerged of whether their findings could be generalized or extended to the women in this study. From the ideologies shaped by their home countries, and the union activity that surrounded some workers and not others, it is difficult to draw on these resources to speak fully on the experiences of Filipina garment workers.

\subsection{Winnipeg's Garment Industry}

As mentioned, there are two sources that provided an overview of Winnipeg's garment industry (Lepp, Millar \& Roberts 1987; Khatun 2005). One looked at Winnipeg's garment industry in the past, from the 1800s to the 1970s (Lepp, Millar \& Roberts 1987), while the other

focused on the garment industry in more recent times (Khatun 2005). Both sources contained 
personal excerpts from interviews conducted with Filipino women about their working experiences, as well as why they decided to immigrate to Canada and the challenges they faced when they first arrived, issues which are all integral to this paper.

In Women in the Winnipeg Garment Industry, 1950s-1970s, Annalee Lepp, David Millar and Barbara Roberts (1987) provided the most informative resource on Winnipeg's garment trade prior to and at the time of the arrival of the Filipina recruits. It outlined the landscape of the city's garment industry, with its specific needs and challenges, which led to the arrival of workers from overseas. It also discussed an inquiry entitled the Swan Commission, which released a report in 1957 that looked into Winnipeg's garment shops. Testimonies were also heard from some of the workers. The inquiry found the conditions appalling, which further illustrated the reasons why Canadian workers were so unwilling to work in the factories. There were also personal experiences from non-Filipina workers, who, before the arrival of the Filipino women, tried to fight for better wages and improved working conditions, with little success. It also included information on the key recruitment official of garment workers from overseas, the countries from which the women were recruited and the companies for which they worked when they arrived in Manitoba. Lepp, Millar and Roberts' findings showed how the policies of the federal government, combined with the actions of the factory owners, exploited women based on gender, ethnicity and class. While it did not detail the experiences of Filipina garment workers, it did show how the actions of the employers and the Canadian government led to profits for the garment industry, by employing cheap labour.

From the demands of other workers, the opposing wants of the factory owners and the subsidies given to factory owners by the federal government, this resource firmly established the 
social, economic and political climate into which the Filipina garment recruits entered once they arrived in Canada. What was missing, however, was insight into the actual working experiences of the Filipino women in question. Only one Filipino woman was mentioned, and the anecdote she offered did not provide any information about her working experiences. The essay therefore merely established the grounds for the research undertaken in this study.

The report, Worker Views on the Changes in the Winnipeg Garment Industry: In-depth Interviews with Ten Immigrant Garment Workers (Khatun 2005), offered information on the working conditions of garment workers gleaned during one-on-one discussions. Amena Khatun summarized her findings and included two case studies to provide more in-depth information of her research. The ethno-cultural backgrounds of the women she interviewed for the case studies were not known, but Khatun mainly spoke with newcomers to Canada and Aboriginal women. The number of interview respondents from the Philippines was not clear. In Khatun's overall profile of her interviewees, she listed the Philippines as one of the countries from which her respondents originated, but she did not list the actual number of Filipino women who participated in the study $(2005$, p. 71). Khatun's findings showed that the women's views of their working experiences in Canada were heavily influenced by their time working in their countries of origin (2005, pp. 86-87), which is also significant to the study of Filipina garment recruits. She also found that Winnipeg's garment industry was divided along gender lines and relied heavily on immigrant labour (2005, p. 89), thus reflecting marginalization based on class and ethnicity. One significant point that she made is that the immigrant women employed in the factories also sponsored their family members to move to Winnipeg, thereby supplying a 
constant chain of workers for the factories (Khatun, 2005, p. 89), and leading to the proliferation of female workers in Winnipeg based on ethnicity, gender and class.

While Khatun's research is significant, it was released in 2005. The Filipina women in the study arrived in the late 1960s and early 1970s. Therefore, considering the differing time periods, with a gap of at least 30 years, the first hand accounts of the interview subjects in Khatun's research will not be entirely similar to the experiences of the Filipino women in question. In addition, the report did not focus solely on Filipina garment workers. However, the larger issues surrounding worker discrimination based on ethno-cultural background, class and gender can still be applied to the Filipino women being examined in the research and their experiences in the garment industry.

\subsection{Theoretical Framework}

Although much of the work that is referenced in this paper was written from a MarxistFeminist standpoint (Frager 1992; Frager \& Patrias 2005; Gannage 1986; Giesbrecht 2010), this research paper will use the theoretical framework of political economy. The political economy perspective deals with "the interaction of political and economic processes in a society: the distribution of power and wealth between different groups and individuals, and the processes that create, sustain and transform these relationships over time" ("Political Economy Analysis" n.d.), which, in the case of the Filipina garment workers, means the movement of a cheap source of labour for the Canadian economy.

Grace-Edward Galabuzi (2006) has written extensively on Canadian immigration policies and their inextricable links to the labour market. The recruitment of Filipina garment workers to Winnipeg can be seen as an attempt by Canada to import cheap labour, and maintain a struggling 
industry (Lepp, Millar \& Roberts, 1987, p. 157). Admitting racialized women into Canada was therefore strategic on the part of the federal government, which carefully encouraged immigration, but, according to Galabuzi, within the framework of a racist policy aimed at maintaining specific relations of domination in society:

Canada's diversity in race, ethnicity, gender, and class has been used to establish government policies and programs that benefited certain groups and disadvantaged others. These policies help entrench positions of privilege and majority status for some, and disadvantage and minority status for others. (2006, p. 29)

Immigration policies also play a role in the opportunities which bring racialized women to Canada. The recruitment of garment workers to Winnipeg fulfilled a need for employees to carry out what is traditionally known as women's work. Therefore, such recruitment inevitably targeted women, not men, so the women who applied were already being marginalized, even before they arrived. As Galabuzi writes:

From a gender standpoint, not only did racialized women face the racial structures in the workplace and society, but also they were incorporated into the "pink ghettos' where women are disproportionately represented. Beyond being imported into the lower ranks of the health-care sector, the textile and garment industry, the service sector and clerical ghettos, and disproportionately subjected to precarious forms of employment, many female immigrants from the global South were forced to apply as domestic workers, although many had professional and other qualifications. (2006, p. 8)

The racial structures firmly in place in Canadian society entrenched Filipino women in subordinate positions. Therefore, while the Filipina garment workers themselves perceived working in Canada as an opportunity, such "opportunity" did not come without costs and consequences. 
As illustrated, concepts from political economy play a significant part in the recruitment of Filipina garment workers to Winnipeg. It is therefore through this lens that the women's migration and working experiences will be examined.

Each of the sources that have been discussed present not just strengths but limitations, as most of them did not speak specifically of the working conditions of Filipino women who migrated to Winnipeg in the 1960s and 1970s as garment workers. Some only discussed the experiences of other racialized groups. This further illustrates the point that there is a significant gap of publications on this topic, thereby requiring urgent attention to this area of Canadian history.

\section{Section 3: Methodology and Research Design}

The research for this paper is based on a qualitative approach as it is the most effective way in determining how Filipino women perceived their own experiences as garment workers in the 1960s and 1970s. The intent of the research is to collect first-hand accounts from Filipina immigrants on their work, in their own words, to determine their opinions and emotions regarding their lives as garment workers. The complexities and nuances of their personal experiences would not be as effectively captured using a quantitative approach.

\subsection{Strategy}

The strategy that was used in this research was personal, one-on-one interviews, to capture in-depth descriptions and testimonials from the participants. The stories needed to be told from the perspectives of the workers themselves, and to reflect this, it was necessary to make 
sure that the methodology was as exploratory in nature as possible. The questions were used to guide the women in their storytelling, not as a tool to hinder or limit their responses.

\subsection{Participant Demographics}

In total, ten women were interviewed, but only eight of the interviews were used in the study. The women who were included in the research all arrived in Winnipeg between 1968 and 1974. The other two women came in 1980, and were not among the first few waves of garment workers to arrive. These two interviews were mainly conducted to determine whether the working experiences of Filipina garment workers had changed over the years.

The women all came from poor, working class backgrounds in the Philippines. Most mentioned that their parents were farmers, fishermen or homemakers. One woman said her mom was already employed in the garment industry as a supervisor. Most of the women had already been working as sewing machine operators in the Philippines. Seven of the eight women were directly recruited as garment workers from the Philippines; one was sponsored by her sister, who was recruited. None were married at the time of recruitment, although some had boyfriends. At work, they were either paid minimum wage or a piecework rate. In terms of their living situations, many of the women lived with several other factory workers to lower their day-to-day expenses, so that they could send as much money home to the Philippines as possible. Their remittances varied, ranging from $\$ 50-100$ monthly. They also took on part-time jobs to increase their income, often working evenings and weekends. These part-time positions were not always in the garment industry: one interview participant said that she also worked as a banquet server in a hotel. 


\subsection{Participant Selection}

Participants were mainly recruited with the help of two key figures in Winnipeg's Filipino community, a school board trustee and a community liaison coordinator who is employed by Winnipeg's largest school division. They approached eligible interview subjects by phone and in person and told them about the research. They provided interested parties with contact information. While the community liaison coordinator and school board trustee are well known in the Filipino community, there was no concern that any potential participants would feel obliged to take part, simply because of the people who asked them. The two liaisons only told garment workers about the research and stressed that it was their decision whether they would be willing to participate.

Participants in the study were also recruited through snowball sampling, which entails finding a few cases and then getting referrals from them for others (Archer \& Berdahl, 2011, p. 379). Willing participants were asked whether they knew anyone else who fit the requirements of the sample and would be willing to be interviewed.

Once willing participants called, they were told more about the research. They were also provided with greater detail about the questions that they would be asked, to gauge whether they would be willing to take part. All the information that was told to them over the phone was prepared beforehand and written out in a telephone script. ${ }^{2}$ The overall purpose of the study, the principle of confidentiality, and anticipated benefits and risks were explained. It was also stressed that their participation was purely voluntary. All the information that was told during the phone call was provided on a consent form ${ }^{3}$ that the women needed to sign prior to the interview.

\footnotetext{
${ }^{2}$ See Appendix A, page 59.

${ }^{3}$ See Appendix B, page 60.
} 


\subsection{Data Collection Tools and Process}

For this major research paper, archival and testimonial research was conducted in Winnipeg in the latter half of May 2012. Much of the time in Winnipeg was spent searching for interview participants, then scheduling and conducting interviews. Semi-structured, one-on-one interviews were used because they were flexible, interactive and allowed for greater depth, understanding and exploration. The women were asked open-ended questions ${ }^{4}$ about their experiences of immigrating and settling in Winnipeg as garment workers. The interviews, carried out in a conversation-style and audio-recorded, lasted from 20 to 70 minutes. Overall, the general strategy for the interviews was to begin with broad questions to set the subject at ease. At times, follow-up questions were asked after the women responded, to ensure complete understanding and to avoid imposing any meanings on the participant's answers. Non-verbal communication was also observed and noted.

\subsection{Ethical Considerations}

The safety and well-being of the research participants was emphasized throughout the interview process, from recruitment to the actual interviews. If the participants felt uncomfortable at any point during the interview, they were informed that they could either refrain from answering a question or stop the interview altogether. In addition, the women who agreed to participate in the study were informed that their identities would remain confidential, allowing them to express their thoughts freely, without any concerns of repercussions. Therefore, quotes from the interviews are included in the following sections, but codes are used to maintain the women's identities, and confidentiality.

\footnotetext{
${ }^{4}$ See Appendix C, page 63.
} 


\subsection{Transcription and Coding}

Each interview was transcribed verbatim and manually coded for themes and content. Specific attention was paid to the working experiences of the women in the factories and their emotions and attitudes surrounding those experiences. The following section will outline the findings discovered from the data.

\section{Section 4: Findings and Analysis}

This section presents the findings of the interviews conducted with eight Filipina ${ }^{5}$ garment workers. The section also cites some of the relevant findings of the literature, documentary and museum work to support the collective narrative that emerged from the interviews. The participants, who arrived in Winnipeg in the 1960s and 1970s, were all asked to reflect on their migration process to Winnipeg, their time in the garment industry and the conditions and treatment that they faced at work. The findings from the interviews will be presented in a chronological order beginning with the women's recruitment in the Philippines, their arrival in Winnipeg and finally, their experiences in the factories.

\subsection{The Recruitment Process}

In the late 1960s, Filipino women began arriving in Winnipeg ("From Manila to Manitoba") to fill the labour shortages in the city's garment industry. Meyer Klapman, the provincially appointed recruiter for the industry, made three trips each to Italy and the Philippines between 1966 and 1970, and hired 700 garment workers en masse (Lepp, Millar \&

\footnotetext{
${ }^{5}$ See Appendix D, page 65.
} 
Roberts, 1987, p. 158), in a move that would help to "hold down the price of labour" (Lepp, Millar \& Roberts, 1987, p. 157). What became evident, after interviewing Participants E and F, was that the Philippines was chosen as a source country at the suggestion of a Filipino woman who, at the time, was already living in Winnipeg:

Participant E: ... Mrs. Custodio, Carolina Custodio... she's at the time at the Immigration, so she suggested, why don't we try some Filipino workers? Because we have so many of them in the Philippines that work in the garment factory. (S. Camia, personal communication, May 28, 2012)

Participant F: ... Mrs Custodio. She works in immigration office. And another, puti [white]... Mr. Cruickshank. There are really very nice immigration officer, they are really very nice to us. They gave us a bed, like for my friend and me, we shared bed. (S. Camia, personal communication, May 29, 2012) ${ }^{6}$

As a result of a suggestion put forth by Carolina Custodio, and the overseas recruitment that followed, 114 Filipino women arrived in Winnipeg in 1968 (Lepp, Millar \& Roberts, 1987, p. 158). This first batch of recruits paved the way for a steady influx of Filipina garment workers, which greatly increased the Filipino population in Manitoba. Federal immigration records show that in 1967, the province consisted of only 6.7 per cent of Canada's entire population of Filipinos (Laquian, 1973, p. 4). In 1971, that number nearly doubled, rising significantly to 12.9 per cent (Laquian, 1973, p. 4).

Since the recruitment specifically targeted women with previous experience in the needle trade, the application process consisted of a general test that determined the woman's age, marital status and education, a sewing test and an interview with the Canadian Consulate (Buduhan, 1972, p.58).

\footnotetext{
${ }^{6}$ During the transcription process, the women's grammatical errors were not corrected, to maintain the authenticity
} of their responses. 
According to Buduhan, (1972, p. 58), the applicant was questioned briefly and examined during the general test. The first applicants recounted their experiences to others, and therefore, through word of mouth, it became widely known to interested parties that the ideal recruit was single, between the ages of 20 and 25 , had completed some education at the high school level and was physically healthy (Buduhan, 1972, p. 58). In other words, the ideal recruit was: 1) not married, so that there would be no dependents, either a spouse or children, to take care of both by the individual (the woman) and the country at large (through social programs such as daycare); 2) physically healthy, so as not to burden the health care system and 3) young, and therefore strong enough to endure the work. As Ralph King, a garment factory owner in Winnipeg, was heard to have put it: “I'm looking for a woman who needs money. I don't want women with kids under six, and they can't be more than twenty pounds overweight” (Lepp, Millar \& Roberts, 1987, p. 158). However, not everyone who was admitted into Canada fulfilled all the supposed requirements: two of the women who participated in the study said that they had only completed the sixth grade, while another woman only finished the seventh grade. Yet these three women all had extensive experience in the garment industry in the Philippines when they applied to migrate to Canada.

If a woman passed the general test, she would be asked to perform a sewing test. For her sewing examination, Participant B said that she was given a scrap to sew, and "the way you're holding it, they know already that you know how" (S. Camia, personal communication, May 25, 2012). Participant $\mathrm{H}$ recalled that they asked her to thread a sewing machine (S. Camia, personal communication, May 30, 2012). 
In the interview with the Consulate, which, according to Participant A, lasted only a few minutes (S. Camia, personal communication, May 25, 2012), the women said that they were asked a number of questions which they found quite easy to answer, including why they wanted to go to Canada, what they knew about Winnipeg, whether they knew anyone who was already there, as well as basic questions about the country. This interview appeared less important than the women's ability to sew. Participant G says she was given a book before the interview so that she could prepare, and the answers to the questions on Canada were contained in the book (S. Camia, personal communication, May 30, 2012). After they passed the sewing test and the interview, they were required to undergo medical examinations. Upon successful completion, they were given visas and passports to move to Winnipeg.

Each of the interview participants spoke of working in Canada as an opportunity for them to help support their families in the Philippines. Therefore, they wanted to make sure all the arrangements were firmly in place before telling their parents. Participant E said that she did not tell her family members that she had applied to go to Canada until all of her paperwork was processed (S. Camia, personal communication, May 28, 2012). "They preferred to leave their parents undisturbed until 'everything was sure"” (Buduhan, 1972, p. 63), because, as Participant E described, they were certain that their parents would object:

Participant E: Oh, you know what my parents did? I said, when I came home, I had my passport already, I didn't even tell them... So when I went back home, I quit my job a week before, and then I told my parents. I said, "Mom, dad, guess what? I'm leaving. I'm going to ride a plane." "What are you talking about? Are you crazy?" (laughs) Something like that... So I showed them my passport and both of them, nothing to say. And they start crying. My mom, my dad start crying. They said, "Is this for real?" I said, "Opo, totoo po yan. Paalis na po ako." [Yes, it's true. I'm leaving.] (laughs) And then they said, "Hindi! Hindi ka aalis. Hindi ka aalis dito. Dito tayo mabubuhay." [No! You're not leaving. You're not leaving here. This is 
where we're going to live.] (laughs) "Dito tayo mabubuhay. Dito tayo mamamatay. Hindi puwede tayo maghiwa-hiwalay." [This is where we're going to live. This is where we're going to die. We can't be separated.] And then I told them, I said, "Mom, dad, it's ok kasi masmakakatulong ako sa inyo." [I can help you more.] I can help you more, you know. (S. Camia, personal communication, May 28, 2012)

Their parents were not the only family members who objected, or had concerns about the opportunity. Some of the earlier recruits recalled facing skepticism among their relatives over the legitimacy of their contracts. These women said that others were suspicious of the seemingly dubious nature of the opportunity to work in Canada:

Participant E: ... some people are saying, ah... "baka gagawin lang yan ng prostitute doon" [Maybe they'll just make her a prostitute there.]... it's even my auntie who said that. (S. Camia, personal communication, May 28, 2012)

Participant H: ... my mom even think that the people that hiring us, they'll do us like a prostitute here in Canada, eh? My mom doesn't like that. I was so scared. (S. Camia, personal communication, May 30, 2012)

To allay some of the concerns, the Canadian Embassy organized pre-departure orientation sessions for the first recruits and their families, to give them a better sense of what to expect in Canada.

You pay nothing. You will even receive money as a start. And the grand fee (transportation) will be paid by the company (Winnipeg factory). The company will give you pocket money of $\$ 120.00$. You will pay back the company $\$ 5.00$ weekly. You are under two years contract in the garment factory. You will not be dealing with light materials or bras like you do here. You will be making heavy heavy [sic] clothing. You will find it harder. Your minimum wage will be $\$ 1.25$ per hour... After two years you can transfer to another factory or to any other place. There is a tax of five cents for every dollar you earn. (Buduhan, 1972, pp. 64-65) 
In other words, the women were told that they would receive their plane tickets and start up pocket money from the factory that recruited them. However, they would have to pay back these costs out of their pay checks, once they began working (Buduhan, 1972, pp. 64-65). Through their contracts, the women were bound to the same factory for a minimum of two years. Yet this contract, which crippled the women's mobility and gave them a semi-indentured status, did not deter them from the opportunity to move to Canada. Instead, the possibility of steady work reaffirmed to them, and their parents, that the opportunity to move was a good one, and one that paid significantly more than the wages that they were receiving in the Philippines.

For the later recruits, they were comforted through their correspondence with friends who had gone to Winnipeg before them, who confirmed that the offer was indeed legitimate:

Participant H: I knew somebody here, and they came in 1968, and then I heard from them, they wrote me a letter that it's nice to live here. (S. Camia, personal communication, May 30, 2012)

With the reassurances and the paperwork in place, the garment recruits left for Winnipeg. For the women, such as Participant A, this would be the first time that they would board planes and travel overseas.

Participant A: I don't know how to put the seatbelt, I don't know how to, when I'm in the airplane, I'll just pray that I may come to Canada safe and sound.

Interviewer: So who taught you who to how put the seatbelt on?

Participant A: Oh, I just look at the one that besides me, or I ask because that's the first time, I don't know anything about that... riding in an airplane. (S. Camia, personal communication, May 25, 2012) 
The women interviewed expressed a range of emotions, from fear, nervousness and a reluctance to leave their families behind, but ultimately, they were excited at the prospect of helping their relatives by earning money and working abroad, a dream that Participants F and E said they had since they were young girls:

Participant F: In the Philippines... one of my dream is to go away, like, you know, to go abroad. (S. Camia, personal communication, May 29, 2012)

Participant E: I just finish grade 6, so I think I was 11. And then sometimes I'm helping my mom doing some laundry... And I remember at that time, every time I'm looking up for the airplane is passing by on top of me there, I said, oh my god, Lord, help me, I wish that I can ride that airplane someday, sometimes! (laughs) That was always my dream, you know, to ride on an airplane. Anyway, so I stop, like after grade 6, I stop going to school. (S. Camia, personal communication, May 28, 2012)

So, the stage was set: in spite of how little the women would be making, compared to the wages that Canadians were earning in Canada, the garment recruits knew that they would never earn the same amount of money in the Philippines. Hence, they all mentioned in the interviews that they saw coming to Canada as a big opportunity. Therefore, the owners of the garment factories, who wanted "strong backs, low wages" (Lepp, Millar \& Roberts, 1987, p.158), found an eager and willing supply of poor workers, who were willing to accept the conditions of their opportunity to earn a higher income, improve their lives and contribute to the well-being of their loved ones.

\subsection{Arrival in Winnipeg}

According to the interview participants, the experience of arrival in Winnipeg differed depending on the year that they came. The women who were among the first batches of recruits spoke of how well they were treated when they first arrived: 
Participant E: Because the government so nice at that time, like, they pay for all our plane ticket, and when we get here, everything is ready. The apartment is ready, we have, everybody had a bundle of a blanket, everything that we need... a blanket... pillow... one plate, one cup, spoon and fork and knives, glass... And when we arrive the apartment is already set up. (S. Camia, personal communication, May 28, 2012)

As described by Participant E, the women were set up with lodging, housing supplies and sleeping materials, all pre-arranged by Immigration officers and an association comprising of Filipinos who had already been living in Winnipeg (Buduhan, 1972, p. 68); the housing supplies were paid for by an advance from the federal government's Manpower Training Section (Buduhan, 1972, p. 68). In terms of living arrangements, the interview participants who were among the earliest recruits said that soon after their arrival, they were divided into groups to live in apartments or houses that were arranged for them by the Canadian government, with the help of the aforementioned Filipino-Canadian association (Buduhan, 1972, p. 68). According to the interviewees, the number of people with which they shared accommodations varied, from four to seven others. Participant B said that the factory for which she worked covered their rent for up to three months to help ease the workers into their new lives (S. Camia, personal communication, May 25, 2012), which, as mentioned, along with the costs of supplies, they were expected to pay back. The women were also given cash allowances and winter clothes, as well as orientations and tours of Winnipeg (Lepp, Millar \& Roberts, 1987, p. 158). However, the incentives did not come without a price: Participant G said that they had to stay with the factory that hired them for two years. If the women did not complete their contracts, they were required to pay the balance for the costs incurred by the Canadian government in their recruitment and settlement (S. Camia, personal communication, May 30, 2012). In addition, the two-year contract guaranteed 
inexpensive labour for the factories, which had had difficulty in retaining workers in the past, under the pretext of providing secure employment for the women. Therefore, what had initially been described by Participant E as a "nice government" was not so nice after all; it did not act purely out of the spirit of generosity in helping the women settle into their new lives in Winnipeg. Some of the first recruits eventually came to this realization. However, none of the interview participants complained about having to stay with the same company for their first two years in Canada.

After becoming accustomed to their new lives, the first recruits took it upon themselves to welcome the newer arrivals. They bought or lent the new workers necessary items to help them settle (Buduhan, 1972, p. 69). The actions of the first recruits were confirmed by the interview participants who came in later years, who expressed it was the first batches of women who helped them acclimatize to Winnipeg, not the Canadian government. Both Participants A and C said that they received assistance from relatives who arrived before them, who helped with the practical aspects of settlement such as accommodations. Participant A said that she lived in a house with six of her relatives who also worked in the garment industry (S. Camia, personal communication, May 25, 2012). Participant $\mathrm{D}$, however, was the only one who recounted a negative living experience: she said that she had initially lived in a house with 13 other people. One of her roommates often complained about having to cook for everyone and made her feel guilty when she left, so she often felt compelled to stay at home. This living situation did not suit Participant D, who said that she eventually moved into a rooming house so that she could have her own space and not deal with the demands and complaints of others (S. Camia, personal communication, May 28, 2012). 
As the women got settled in their new homes, they also started feeling homesick.

Participant $\mathrm{C}$ said her sister, who was among the earlier recruits, gave her essential advice on how to cope:

Interviewer: So what sorts of advice did your sister... tell you about Winnipeg?

Participant C: She said, "You gonna be... homesick. You gonna be homesick when you came here, but you have to try, you know, you have to try to avoid that homesick."

Interviewer: How did you try to avoid it?

Participant C: Oh, to be (with) my sister and my friends, mostly at the time, every weekend we are getting together with some of my friend. They came here at the same times with me. (S. Camia, personal communication, May 26, 2012)

The assistance of the earlier recruits would prove invaluable as the interview participants said that they did not have much time to get used to their new home before their first day at work. They had from a few days (Participant D) to a week (Participants A and C) to get settled before reporting to their employers. The following section will outline the women's experiences at work in the various factories, from the job of sewing itself to their interactions with co-workers and the management.

\subsection{Work}

According to the interview participants who were part of the first batches of recruits, when they first arrived, they did not know for which company they would work. Both Participants E and $\mathrm{F}$ described the selection process that occurred when they arrived in Winnipeg: 
Participant F: Ok, the first batch, what they did is they brought us to Empire Hotel. The first group was left, we were left there, we stayed there overnight, and then the next morning, there are like, representative from different garment factories and they divide us in different groups. And then, after that, after they divide us, they brought us to their clothing company and that's where decide us, what we have to do. That's how we started. (S. Camia, personal communication, May 29, 2012)

Participant E: ... when we arrive, we don't know what factory is gonna take us. So, at first, we are all, we stayed at the hotel... we stay there for the night, and the next morning, all this manager from other factory that needed some worker, they're all in there, like, seems like... it's look like a marketplace! That we are all for sale - who wants to get this, and how many needed, and things like that! So, I had a friend that I meet already in the hotel. So I said, "Whatever factory you're gonna go, I'm gonna go with you." So that's what happened. So Peerless Garment needed seven girls. So the girl that I was telling you, she went to that Peerless Garment, so I said, "Ok she's going, I'm going with her because she's the only person I know in that group!" So that's where I stay. And that Peerless Garment is still alive, still going... Yeah, that's the factory I went for two years. (S. Camia, personal communication, May 28, 2012)

What is interesting to note is that Participant E had described the selection process as being similar to a marketplace, suggesting that the women were for sale. However, she had laughed while recalling the event, demonstrating her lack of any negative emotion. Furthermore, when Participants $\mathrm{F}$ and $\mathrm{H}$ recalled taking part in a similar process, they too relayed the information in a manner that appeared more amused by the experience than upset. Despite their reactions, the method by which the factory owners chose their employees still epitomized, from a political economy perspective, the view that the recruits were nothing but cheap labour: the women were rounded up, divided, then chosen based purely on physical appearance. For instance, Participant H said she was chosen quickly because she was taller, and thus her body was bigger, than the other recruits in the room:

Participant H: When we came here, they put us in a hotel. They make us by group. They told us to get your own group, five by five. So we put ourselves in a table, five 
of us, and the manager of the factories will pick you up, which one he likes. And so I'm big, he said to me, "I like her, I like this group." Ok, so they took my group. (S. Camia, personal communication, May 30, 2012)

Being bigger implied being stronger, and therefore, more capable of strenuous tasks. As the women discovered in the first few days of employment, this requirement of being strong was an important one, for the work was much more difficult, and the materials much more heavy, than they were accustomed to in the Philippines.

Participant G: For me, it's hard, like we're working in a coat factory. It's very heavy.

Interviewer: Which company?

Participant G: Western Garments. It's heavy, like the wool, not like in the Philippines, we're working in baby dresses, or bra. Something like that. But here, it's heavy. It's heavier, but I finish my contract of two years. After that, I move to the other company. (S. Camia, personal communication, May 30, 2012)

Participant H: (While working at) Canadian Sportswear... we make coveralls, you know. And the coveralls is 12 in a bundle. I can't even lift it. I drag it. I'm so weak I can't lift them. And this lady, the German lady, she's up to here [ed. points to her shoulder], when she hold a bundle, she throw it like this, oh my god!

Interviewer: So she only came up to your shoulder and she could do it.

Participant H: Yes! White people are very strong, I said. Why? We big than they, ${ }^{7}$ but we don't work very hard in our country. Imagine brassiere. What brassiere. You know when you make the cups, it's only small one... And I ruin my finger.

Interviewer: The first day?

Participant H: Within two weeks. Because you know, when you sewing, you rub like that, eh? All my fingers here -

\footnotetext{
${ }^{7}$ At 5 7", Participant $\mathrm{H}$ is taller than most Filipino women, so while the rest of the interview participants may have been considerably smaller than their co-workers, Participant $\mathrm{H}$, in contrast, was considerably taller.
} 
Interviewer: At the tips, yeah.

Participant H: I put tape in them. You know, when you put tape, the skin is getting softer and softer, it get worse. So when I get pregnant, I quit that job. (S. Camia, personal communication, May 30, 2012)

Despite the challenges of the job, Participant H still stayed with the same company for nearly three years, fulfilling her 2-year contract and, as she put it, "giving thanks" to her boss because she would not be in Canada had it not been for that opportunity (S. Camia, personal communication, May 30, 2012). Yet, as Participants G and H mentioned, the work was physically difficult, so although they did not complain verbally to their employers about the working conditions and they were grateful for their chance to come to Canada, after the mandatory 2-year period, they chose to move on and find work at other companies.

However, at the beginning of their contracts, Participant $\mathrm{H}$, and the other interview participants, were eager to learn and impress their new employers. The employers, on the other hand, were curious about how well the women would perform:

Participant F: They watch us. One of the supervisor will come, sometimes they, we have a test, you know, they time us to find out whether we're really working good. Yeah, that's how it is. They watch us, they are always all around us.

Interviewer: And how surprised were they when they -

Participant F: They were surprised! They like us so, since then... And we speak English, so yeah. (S. Camia, personal communication, May 29, 2012)

Some of the women also said that they wanted to do well and be productive because they were working at a piecework rate, which entails a worker getting paid per piece instead of per hour (Frager \& Patrias, 2005, p. 21). In other words, they believed that the more work they completed, 
the more money they made, and therefore, the more remittances they could send to the

Philippines. However, despite the perceived benefits of the piecework system, it was not set up to favour the employees, but the employers:

(T)he system of piecework was used to speed up workers. Under this system, instead of paying the worker a set wage per hour, the worker was paid according to the number of items (or parts of items) she or he had produced. Instead of timing average workers, employers frequently set piece rates according to the time required by the fastest workers. When they believed that workers were able to earn too much money under the established rate, employers often reduced piece rates. As factory inspectors emphasized, piecework seriously strained workers' nerves. (Frager \& Patrias, 2005, p. 21)

Gannage's findings reflect those of Frager and Patrias, asserting that piecework was a stressful, demanding system that overworked employees and ultimately "manifested itself in physical illness" (Gannage, 1986, p. 122). While some of the workers in Gannage's sample did like piecework for similar reasons to the women interviewed in this study, overall, the people that she interviewed abhorred the piecework system, saying that the employer-imposed necessity to rush through their jobs not only affected their physical health, but also made them feel like slaves and animals (Gannage, 1986, pp. 122-124). Initially, as with Gannage's findings, some of the interview participants, such as Participants $\mathrm{C}$ and $\mathrm{E}$, did not understand the dynamics behind piecework and would continue to work quickly. This ceaseless routine of uninterrupted, fastpaced work, coupled with the pride of the workers in their ability to get the job done, is precisely what the employers were seeking in their quest to produce more output and generate more income, for the factory and themselves. However, Participant E mentioned eventually becoming aware of the exploitative nature of piecework after speaking with some of her non-Filipino coworkers: 
Participant E: Some of your co-worker said, "Don't work so fast because the price is gonna be down." And we don't understand at the time... We are here, like I'm thinking, we are here to work. If I make more, I make more money.

Interviewer: Oh was it piecework?

Participant E: Piecework, yeah, it's piecework. So why should we slow down? How you gonna do slowing down when you are working and you're concentrating really, you know, and you want to show off! Of course... And then you finish before them, and they get upset.... They said, "No, no no..." Said, "No, because uh, price -- go -down." Like, price go down. And this is how I remember. What price go down? Ah, after that I realize that they don't want me to work fast because the price will go down. And if the price go down, it's no good for them and it's no good for me. But then, I don't know, the Filipino, they don't know how to slow down.

Interviewer: So they were obviously threatened by it.

Participant E: Oh yeah, they do. They do, because they want to make good money, but they don't, because what I understand, because when you work faster, and then the work will be finish faster. And when they see that you're making good money, they gonna cut down the price. But for us at the time, we don't understand that much, what they mean. So we just work. And then we know that people are watching us. So we have to work. (S. Camia, personal communication, May 28, 2012)

The women's need to work is motivated by the desire to form a good impression on their employers and to send money home. Due to this desire and their commitments to their families in the Philippines, the women also took on part-time employment. All the interview participants said that they would go to work five days a week, eight hours a day, Monday to Friday at various factories, sewing items such as pants, coats and overalls. They would also work overtime hours when required. Participant E revealed that she worked extra hours as a way to combat her homesickness (S. Camia, personal communication, May 28, 2012). When she first arrived, she mentioned that she had often cried because she missed her family back in the Philippines (S. Camia, personal communication, May 28, 2012). Therefore, working solved two problems: 1) it 
was a form of distraction that allowed her to be surrounded by other Filipinos who became her friends and 2) it became a way for her to further help the family that she had missed so greatly.

In the evenings or on the weekends, the women would go to side jobs to generate further income. Yet despite the prevalence of holding up to three jobs at the same time, Participant $\mathrm{H}$ said that under the contract with their full-time employers, they were not allowed to take on any part-time work. Therefore, whenever they brought up the topic at their full-time jobs, they would speak in code so that their employers would not find out (S. Camia, personal communication, May 30, 2012). Participant $\mathrm{H}$ said that they spoke in Filipino when referring to their part-time employment, referring to it as bocaue (S. Camia, personal communication, May 30, 2012). Bocaue was a colloquial term used in the Philippines to describe work performed at night, specifically, in a night club. The women, however, made the term their own. They did not work in night clubs in Winnipeg, but some of their part-time work was performed in the evenings, which is why they referred to it bocaue (S. Camia, personal communication, May 30, 2012).

While their work ethic impressed their employers, their co-workers, on the other hand, were not as impressed by their arrival. The following is the reaction of one Canadian-born garment worker:

I figured, cheap wages, eh? Here comes some more! Well, I feel that if [the manufacturers] would have paid a decent wage they would have had all the help right from here. The only reason to go out there [overseas] is to pay cheap wages... I didn't think it was a threat to my job but it was a threat to my pay. You were fighting like crazy to get your price and when they came in, I think they would have worked for anything, nothing. You were fighting like crazy to get two dollars an hour when it was $\$ 1.75$ and they would have been satisfied working for a buck... Some of them are six or eight girls living in one-room apartments and they sleep at different times, they all work different times... save on rent, save on food (all they eat is rice anyway) and then they go back home and they're rich... (Lepp, Millar \& Roberts, 1987, p. 160) 
The interview participants, especially those who arrived among the first recruits, also reported negative encounters with their co-workers, particularly, fellow immigrants. Participants F and E mentioned feeling excluded when they first arrived:

Interviewer: What about your coworkers? How did you... feel that you fit in or get along with your coworkers when you first started?

Participant F: Oh, at first they discriminated us, like, you know, it's a mix of Portuguese, Italian, and Greece, you know Greece people. And they just look at us, especially when sometimes we're eating rice for lunch, and they're just wondering, "What are they eating?" Like, discrimination. That time, discrimination was really bad, yeah.

Interviewer: How did you get away from that? Or, you know, start to integrate?

Participant F: Oh, yeah we smile, we talk with them, you know, working with them, eventually, little by little, they know us and they learn that we are friendly. So, it was ok, no problem, yeah. Anyway they're all immigrants too, so they know the feeling, yeah. (S. Camia, personal communication, May 29, 2012)

Participant E: They will not tell you in front of you, but you can see the way they move, like the way they look at you, or the way, they won't say a bad words about us, right, but the way they act, you know exactly that they didn't kind of like you, especially the other worker, and they know that you are beating them, like they know that you are making more than them, yeah. You feel, you can really feel it, but no words.

Interviewer: Were they Canadian-born or were they also immigrants?

Participant E: They were also immigrants. And then sometimes you can hear the supervisor, "How come the girl is making more than you and you've been working there for 15 years? What's wrong?" So you can hear, you can hear that they're getting scolded by the supervisor, 'cause why we are just a newcomer and we can do it and not them? (S. Camia, personal communication, May 28, 2012)

Participant D meanwhile recalled one experience of racism, saying that she and other Filipinos were called mosquitoes because they grouped together and were noisy (S. Camia, personal 
communication, May 28, 2012). However, what is significant to note about Participant D's experience of racism is that unlike Participants F and E who were subdued when they relayed the experiences of being excluded by their colleagues, Participant D laughed and said that she did not care that she was called a mosquito. Her reaction demonstrates that she felt that the namecalling was done in jest, despite the negative nature of the comment.

As illustrated in Participant E's anecdote, the feeling of threat that the Filipina recruits incited among immigrants from other countries was further stoked by factory management. However, divisions were not based simply on ethno-cultural differences. Rank in the workplace also constituted an important basis for division. The interview participants who became supervisors said they felt tension from other Filipinos:

Participant E: It was really a challenge for me when I move to Westcut because girls, Filipino girls, they're so, so mean. They're so mean, like, so many mean girls there that, same Filipino, and sometimes, when I turn around, you can, you hear them, "Oh, kala mo kung sino yan. Tanga tanga naman. Yan." [Who does she think she is? She's stupid.] See, you can hear all those words. So one day, I challenge one of the girl. I said, "Gusto mo [do you want], we change position? I do your work for an hour, do mine for an hour. Do you wanna try?" Because I said, "You don't tell that I'm tanga tanga [stupid]. I'm not gonna be in this position if I'm tanga [stupid]." I said like that. (laughs) So I'm kinda upset because I hear behind my back. And I said, "Get up, get up from your machine. I do your work. Do mine for an hour. And see I'm not just walking around here." Oh, after that, she become my friend. Because I'm not joking. I said, "You know, before that job come in your hands, I do it first, in the evening, to make sure I have the right timing, I have the right position, holding the material together, and start sewing it." So, I said, "So don't say anything like that. I don't wanna hear that. Yeah, I'm challenging you. Do my work for an hour, I do yours, and see what happen." So she become my friend, anyway, she become my friend after that, until now! (laughs) (S. Camia, personal communication, May 28, 2012)

Participant H: My co-nationality sometimes, I don't know what it is, but sometimes they get mad at you without you knowing it. But they don't show it to you. They hide it. Then they talk behind you... Sometimes, like one time, there's a Christmas party, 
you know, usually on Christmas they give gift to the supervisor... And one of these girl thought, because she give a gift to me, like they share the money, 1-dollar each or something like that, then they buy something for you. I'm lucky I didn't open it. I put it on top of the table. I didn't open the gift. The first time I was supervising in Junior Wear, and this lady was saying, because she have lots of repair, I told them, "Inside the factory, I'm not your friend, I'm your supervisor. But outside, we're all friends. We're all Filipinos. Here, we have to respect our job. If we like to keep our job, then respect our job, k?" So I thought the girl, because the girl is very old, she's older than me. And this was there for so long, and me, I'm new. I become supervisor, you know. And this lady says, "Oh my god, she said, I give her a gift, and now she wants me to do all this repair." And I said to her, "You know what, don't worry, I give back the gift. I want you to do that on your time." I used to help her, eh. "On your time. I'm not gonna help you. You do it on your time."

Interviewer: Did she tell you this or did she tell other people?

Participant H: She tell other people and the other people tell me. And before I believe, I talk to her. I said to her, "You know, the gift that you give to me, I didn't open yet. I can give it back." And the other girl says, "Why, she give only 1dollar!" (S. Camia, personal communication, May 30, 2012)

Yet despite a few experiences mentioned by the women, the research findings indicate that on the whole, there were very few perceived experiences of unjust treatment or racism among the Filipina garment workers interviewed for this paper. Interestingly, Participant A even asked why the employers would treat them poorly if they did all their work (S. Camia, personal communication, May 25, 2012). In other words, they gave their employers no reason to complain. The interview participants all worked hard, and were proud of being known as hard workers. Participants E and F, who were among the first recruits, also mentioned how proud they were that their contributions and reputations as good workers led to the recruitment of more Filipino women. Meanwhile, the garment factories benefitted from employees who did not complain, fulfilled their 2-year contracts and worked hard. As a result, the companies were able to reap the benefits of the women's work ethic, without having to pay a large price. 


\section{Section 5: Discussion}

This study was conducted to find out how Filipina women perceived their experiences in the garment industry, how they were treated as employees, and what experiences of racism or unjust treatment they received from their co-workers. While there is, as mentioned, a dearth in resources on this topic, the existing literature on Winnipeg's garment industry and other ethnocultural groups working in garment factories indicates that the workers reported feelings of being exploited, which, in turn, led to organization and resistance. However, the interview findings suggest otherwise: the participants recalled only a few instances of perceived racism and unfair treatment and they tended to interpret certain relations in different ways. The women's interpretations of their experiences can be attributed to the following factors: 1) the fact that their conditions in the same sector in the Philippines were worse; 2) low expectations and job opportunities; 3 ) the sense of pride in sending money and improving conditions for their family at home and 4) limited social and political exposure to ideas and environments challenging the status quo.

\subsection{The Fact that their Conditions in the Same Sector in the Philippines were Worse}

The women's perception of fair treatment in Winnipeg may stem from their origins: when they assessed their working conditions, they did not do so in comparison to other (unionized) workers in Canada or a labour standard of ideal conditions. Their ideas about work were formed on the basis of their experiences in the Philippines, with strict managers and very little pay:

Participant C: We used to work in the Philippines, that once the bell start, you have to work. So we are doing the same way, like what we are doing in the Philippines. Because in the Philippines, it's very stricted, you know, restricted... 
Interviewer: Were you treated unfairly in the Philippines?

Participant C: Yeah, but it's, like what I said, they, the manager in the Philippines is very stricted. What do you call that? ... Mahigpit.

Interviewer: Really strict.

Participant C: Yeah... It's very different between the managers in the Philippines and the managers here. (S. Camia, personal communication, May 26, 2012)

Therefore, when juxtaposing the working experiences of the interview participants in the Philippines with their experiences in Canada, it becomes clear that they truly believed they were better off in Winnipeg. Despite the situations of Canadian-born workers and workers of other racialized backgrounds, who had endured long hours, the physical and mental strain of piecework and low pay (Frager \& Patrias 2005; Gannage 1986), the Filipino women believed that they were making good money, especially when their dollars were converted into pesos.

\subsection{Low Expectations and Job Opportunities}

An interesting discovery that emerged during the interviews is that when the women were asked if they had ever wanted to work in any job other than sewing, some did not appear to understand the question. For example, when Participant A was asked whether she wanted to do anything else with her life, she spoke more of the necessity to work than the luxury of choice:

Interviewer: Did you want to do anything else?

Participant A: We have no time to do anything else because if you're the only one who's working, you have to... nobody will help you, so... you have to... work and work and work to earn money. 
Interviewer: But did you want to do anything else? Did you have any other interests for any other jobs?

Participant A: Because on that time, garment worker is earning much that working in other company like in the hospital. They're only giving minimum wage, so in garment working, worker, the garment workers... if you're a piece worker, you earn more than working in a hospital. That's why we don't think that working in a hospital is better than working in a factory. (S. Camia, personal communication, May 25, 2012)

Even when the question was repeated, Participant A did not stop to reflect on whether she had any other aspirations when she was younger. She continued to reason that her choice was made simply for the sake of money, as though interests had nothing to do with generating income. She also said that she came to Canada because she compared herself with relatives who migrated as garment workers before her, saying that if they could do it, she could too (S. Camia, personal communication, May 25, 2012). Her responses reflect her ethno-cultural background and class: a background of poverty and a limited frame of reference in terms of socio-economic mobility in Canada. The limited opportunities that Participant A saw for herself proved ideal for garment worker recruiters, as the lack of perceived alternatives and possibilities women such as Participant A had implied that they would stay in their poorly paid positions for long periods of time.

Like Participant A, Participant C also spoke of being good at sewing, so she stayed with it (S. Camia, personal communication, May 26, 2012). With limited education and a pressing need to help, workers such as Participants A and C could not afford to think about or pursue anything else. This mindset of limited opportunity was also evident in the interview participants who rose to supervisory positions. Despite their relative success, they did not believe they were worthy of 
the same bonuses as their (non-Filipino) colleagues in management. During her interview,

Participant $\mathrm{H}$ recalled a Christmas bonus that she received one year:

Participant H: I start in October, December we have a party... General Manager's party, k? So we were invited. Me and my husband. We were there, and they give us a bonus. They give us on an envelope. And I'm wearing a coat, and I folded the thing and I put it in my pocket. And my husband is so curious, he said to me, "Can I see how much bonus you have?" Oh yeah, it doesn't bother me. I thought it's only 1week pay, or maybe 100 dollars, k? I thought that's all. So he said to me, "Oh my god." I said, "Why?" "Are you sure this is the money you have?" he said to me. "Why? How much?" "5000." I said, "No, maybe 50 dollars," I said to him. And he said, "No, I almost shoot myself on that toilet bowl!" he said. "Oh really?" So I went to the toilet also to look... Oh my god, it's 5000. I said to my husband, "Maybe they make mistake. I work only three months to be a supervisor!" And my husband says, "Oh, you might pay for that if you spend that!" So the next working day, I went to the office. I went to Mr. Brownstone. I said, "Mr. Brownstone, are you sure you didn't make mistake?" "About what?" "About the check that you gave me?" "No," he said. "It's too much," I said. And he said to me, "Is it?" "Yeah." "No, you deserve it. You work hard. From October until December, we make good money because of you." "Really?" "Yeah, you deserve the money." I share the money with everybody. You know how much money that boss of mine that screaming at me and swearing at me? He got a 4-wheel drive jeep!

Interviewer: That was his bonus money?

Participant H: Yeah, that's his bonus! And mine is 5000! Nothing to it, eh?! But I said, "That's too much!" First time I hold 5000 dollars! (laughs) I said, "Oh my god, it's too much!" So he said to me, "Can I have a little bit?" I said, "Yeah, I buy you a suit!" I didn't know how much money I'm gonna get. I thought it's only 100 or maybe one pay check. You know. My pay check is 450 dollars, so I said, maybe that's how much I'm gonna get. (S. Camia, personal communication, May 30, 2012)

Participant H's bonus gave her insight into the amount of money that the management was earning, setting them vastly apart from the sewing machine operators who were providing the labour. This experience is crucial as it is the first time that one of the women understood the pay inequities that existed, and that, perhaps, what they described as fair treatment was not as fair as 
they had perceived. However, among the interviewees, Participant H's case is unique: she was only one of three interview participants who had the privilege of being promoted to supervisor, and was therefore eligible for such bonuses. As well, despite the fact that Participant H's employer felt that she was deserving of her bonus, she herself felt otherwise, which speaks to the larger disconnect of these women to greater earning power. As women from poor backgrounds, receiving such large sums of money was unheard of.

\subsection{The Sense of Pride in Sending Money and Improving Conditions for Family at Home}

Even though they earned what Canadians considered low wages in the garment industry, the Filipinas' earnings instilled pride, as they became responsible for their families' livelihoods in the Philippines. They were conscious of the fact that it was through their remittances that their relatives' daily lives were made better. For example, Participant G said that her parents were able to install a water pump at their home; before then, they would have to fetch their water from across the river (S. Camia, personal communication, May 30, 2012). Participant H said that her mother was able to build two houses in the Philippines with the remittance money (S. Camia, personal communication, May 30, 2012). As a result, another picture of the women emerged:

While many women faced limited job opportunities, difficult working conditions, and low wages, they were not simply victims... they were active agents in the paid labour force, manoeuvering within sharp constraints to make the most of their limited options. Some obtained a sense of satisfaction from doing their jobs well, even though the jobs could be tedious. (Frager \& Patrias, 2005, p. 29)

The women interviewed for this study reflect Frager and Patrias' assertion: they were not just victims of their fate, rather, they were active agents who saw Canada as their chance to change their and their families' lives. 


\subsection{Limited Social and Political Exposure}

While socializing with other Filipinos was a valuable means of bonding, connection and a source of support during the women's initial adjustment to Canada, it may have also been a hindrance: by only associating with like-minded individuals, they were not easily exposed to the viewpoints of others from different backgrounds. This lack of exposure to others' perspectives, combined with their previous experiences in the Philippines, working and otherwise, led the factories to benefit from the women's hard work and their acceptance of low pay. Therefore, according to the findings of a report looking into Winnipeg's garment industry (Khatun 2005), the limited interaction with other ethno-cultural groups may have also been a factor in the lack of protest activity:

Interviewed workers reported that the immigrant workers of the Philippines and China tend to form close-knit worker groups that exclude others. Other workers also become grouped in terms of their culture and nationality. Such groupings restrict the opportunity of interaction among workers. Moreover, the minority group of workers always feels intimidated by the larger groups. The respondents identified this regionalist tendency as a barrier for trade union movements. They also argued that factory management has tended to disregard these divisions among workers. (Khatun, 2005, p. 80)

As Khatun's finding's indicate, the tendency for Filipino workers to form their social identity mainly around ethno-cultural ties, rather than class commonality, undermines the potential class solidarity among workers, which proves difficult for mobilization.

In the findings of this study, with the exception of one incident, the women made no mention of any type of protest activity, and again, very little was said about any unfair treatment. The findings prove an interesting contrast to Buduhan's findings (1972) and the museum exhibit ("From Manila to Manitoba") that were mentioned in the Literature Review. As mentioned, 
Buduhan witnessed and experienced negative treatment first-hand, including sexual harassment among Filipino garment workers (1972, p. 149); the museum exhibit featured a panel displaying Filipina garment workers on strike in 1981. Many of the women who took part in the interviews were still involved with the garment industry at that time, so it is curious as to why they would not have brought up the protest; the strike would have perceivably been an anomaly in their experiences, since the women said, for the most part, that they were treated fairly by their employers.

The women, did however, mention that there were unions. Yet they did not say whether they supported them. Participants A and D mentioned they joined for security reasons, saying that the union would fight for the employees should problems arise (S. Camia, personal communication, May 25, 2012; S. Camia, personal communication, May 28, 2012). Participant $\mathrm{C}$, however, was rather blunt in her opinion:

Participant C: I don't like union.

Interviewer: Why not?

Participant C: Because when we say something, on the factory, they said, ok, we gonna do it, we gonna do it. Pero [but], after nang [the] meeting, they didn't do anything.

Interviewer: What would people tell the union to do?

Participant C: Everybody get upset because of, especially the minimum wage at that time, they want to increase, you know... and if there's some, if they are, some problem, they keep saying, we gonna fix it, but they didn't do anything. (S. Camia, personal communication, May 26, 2012)

While the clustering of Filipina workers proved a barrier for union activity, as Participant C illustrates, so too did individual mindset. Not only did unions have to penetrate the social 
groupings of Filipino women to get their message across, as the mindsets of Filipinas were not homogenous, the unions also had the difficult task of trying to persuade individual workers to support them.

The women's camaraderie with other Filipinos, often speaking in their own language, also proved a barrier in acquiring fluency in the English language. While the interview participants spoke basic English, many, including Participants A and C, still lacked confidence in their abilities, saying they “can’t speak English.” Gannage's findings also reflect a lack of self-esteem among workers who did not have a firm grasp on their written and spoken English, leading to a reticence to become involved in political organizing (1986, pp. 180-181). This lack of confidence may have also played a role when it came to applying for work in other fields. Yet a higher level of competency in the English language was needed to break out of the garment trade and find better employment elsewhere, where there could be the possibility of increased communication and solidarity with non-Filipina workers:

Unlike white, Canadian-born women with knowledge of one of the official languages, women of colour and non-English-speaking women within the garment industry have no security, no promotions, earn superexploitative wages often paid by the piece, and work in unsafe health conditions. Unlike white, Canadian-born women, these women are "stuck" in a "captive" labour force due to structural and institutional practices. (Gupta, 1996, p. 55)

The women's experiences reflect Gupta's assertion: even in the hiring stages, their education appeared secondary to their ability to sew. The questions that they were asked revolved primarily around whether the women already knew people in Canada and what they knew about Winnipeg. As Participant $\mathrm{G}$ mentioned during the interview, they were given a book to read for the 
questions concerning Canadian history (S. Camia, personal communication, May 30, 2012).

Participant E, however, recognized the limitations of only socializing with other Filipinos:

Interviewer: You said that you had left (the garment industry) after two years because you wanted to learn English. Can you tell me a little bit more about that?

Participant E: Ok. Because I don't have a chance to go to school. 'Cause I'm working... three jobs at the time. So what I did after my 2-years contract, I left, and I started, I'm looking at the places where I can do work. And so I start working at Salisbury House coffee shop. I said, if I get a job in this restaurant, no Filipino, I am going to be forced to speak English. (S. Camia, personal communication, May 28, 2012)

Participant E was the only woman who expressed the need and desire to improve her English abilities. Despite returning to the garment industry a decade later, she says her language acquisition helped her become promoted to supervisor (S. Camia, personal communication, May $28,2012)$

While the interview participants, overall, did not complain about unfair working conditions and did not report any experiences of protest activity, this did not signify that they were merely meek and obedient workers. Two of the supervisors, Participants E and H, demonstrated strong and feisty personalities, not only in their recounted experiences as supervisors, but in the manner in which they told their memories. Participant E also shared a story in which the women she had been supervising staged a protest against factory management, upon hearing she was fired:

Participant E: ... You should see the girls in the factory. They stop for couple hours working. No one is moving. You cannot hear no machine at the time when they find out that I was fired. They are all supportive of me. No one is working for two hours. And we were in the office watching them. They said, "(name of Participant E), what's going on there? They're not working." "I have no idea." And... then after that, they start knocking at, with the scissor, on the table of their machine, said, "We want (name of Participant E) back. We want (name of Participant E) back." Like they 
wanted me to go back, like on the floor. So, I came out, and I told them, I said, "I think this is it for me. I'm fired. And you guys have to continue working. Otherwise, you all not gonna have any job." They said, "It's ok. So they don't have no garment anyway if we all quit at the same time!" I say, "No, your family needed you, and you need a job too. So just keep on going." (S. Camia, personal communication, May 28, 2012)

So while there was little mention of any protests among the interview participants, incidents such as the one stated above did occur during their time in the garment factories. Again, the lack of recalled experiences of resistance or mobilization may not necessarily be a sign of weak character. Their strength may not come in the form of large, organized protests, rather in the quieter forms of hard work, knowing that they could not afford to lose their opportunity to earn money and support their families, and as seen in Section 4.3, simply choosing to leave one job for another, for better working conditions, and better pay.

It is important to understand the complexity of this topic. The women were indeed being exploited by factory owners in Winnipeg, and the Canadian government was complicit in this exploitation by offering help to the factories through various subsidies and programs, which led to major growth and profit for the factory owners (Lepp, Millar \& Roberts, 1987, p. 167), and boosted the overall economy of the province, and the country. The Canadian government also directly took advantage of the women through poor labour, safety and health standards that put their well-being at risk (Lepp, Millar \& Roberts, 1987, p. 167). The women, however, saw themselves as taking advantage of an opportunity that offered them more money than they were making in the Philippines, and were happy and proud of the fact that they were not only able to support themselves, but their families back home. Yet the women did not know the circumstances that were thrust upon them as they were recruited. They lacked adequate 
knowledge of the situation, rendering them, from a Canadian perspective, more content than dissatisfied, unlike the garment workers from other racialized backgrounds who came before them.

\section{Section 6: Conclusion}

\subsection{Strengths}

This study helps to fill part of the gap in existing literature on this topic, and sets the stage for even further research to be conducted. Personal interviews, which included open-ended questions, allowed for discussions of greater detail, open and honest reflections and ultimately, a richer understanding of Filipina garment workers' working experiences in Winnipeg, thus fulfilling the aims of this project.

\subsection{Limitations}

In terms of the study's limitations, five were significant: 1) the challenges that the women faced in explaining their experiences in English; 2) the women's memories, and hence, the credibility of their narratives; 3 ) the role of nostalgia; 4) the lack of time for repeat interviews and 5) the generalizability of the findings. The English language abilities of the interview participants greatly varied: some were more proficient than others, but, as seen through the selected quotes from the interviews, none of the women spoke the language perfectly, often making grammatical errors. While they were told that they could speak in Tagalog, the national language of the Philippines (Belvez, n.d.), the majority chose to converse solely in English. Therefore, they may not have been able to expand on their thoughts and experiences with enough 
detail and as clearly as possible; this may have been remedied had they also chosen to answer the questions in their native language.

Another limitation to the oral histories is memory, and the accuracy of the women's recollections. Much time has passed since the women first arrived in Canada and began their work in the garment industry. For some of the first recruits, they were asked to recall, and describe in great detail, experiences from nearly 45 years ago. Therefore, while some of the women vividly remembered their experiences, others had trouble remembering the names of places, people, or the companies for which they had worked. For example, one of the participants became confused with sections of her work history and had to correct some of the statements that she had made in earlier parts of her interview. She forgot one of the factories at which she had been employed for several years, as well as the main reason why she left the garment industry. In light of such issues with memory, credibility inevitably emerges as a limitation. The women's first-hand accounts of their working experiences therefore present both a strength and a challenge: while the women provided insight into the working lives and experiences of Filipina garment workers, the interviews are predicated on the belief that their responses were accurate. There is little reason to question the women's overall stories, but it is clear that some of their responses cannot be fact-checked and therefore, must be taken at face value, even if some of the details may have been forgotten or confused with time.

Nostalgia may also play a role in the women's narratives. As mentioned, much time has elapsed since their first days in Winnipeg as garment workers. Therefore, their memories may be selective, veering more towards remembering the positive aspects of their experiences than the negative ones. To illustrate this point, a number of women, including Participants B and C, 
mentioned the sense of sisterhood that they felt with their co-workers, when they were asked to reflect on their lives in the garment industry:

Participant B: On that time... I'm happy, because all the workers that, who work with me, it seems like a family also... It seems that, yeah, like I says, it's a family. (S. Camia, personal communication, May 25, 2012)

Participant C: For me, it's... happy. Because I met lots of friends, you know. (S. Camia, personal communication, May 26, 2012)

Such remarks were consistent among the study participants. As previously noted, the women reported few instances of working conditions and treatment that they deemed unjust. They mostly shared stories of their hard work and efforts, often in numerous jobs, so that they could send remittances home to the Philippines.

Time is also a limitation to the study. Given the time constraints of writing this paper, it was not possible to sufficiently probe the women about the working conditions at the factories. These interviews merely scratch the surface of this vast topic. Repeated discussions with the women may have led not only to an increased comfort level among the interview participants, but perhaps more time to reflect and remember more of their experiences as well. In addition, more time would have allowed for further interviews with not just garment workers, but others who would have been able to provide analysis and an overall picture of this topic in greater detail.

Generalizing the findings of the interviews also presents a limitation as the sample used in the study is rather small and specific. The focus of the research was to garner accurate, in-depth accounts of the working experiences of Filipina garment workers who migrated to Winnipeg in the 1960s and 1970s, in order to document this under-studied, but 
major part of Winnipeg's, and ultimately, Canada's history. However, as women from a developing nation who came into the country to perform gendered work, and with limited chances of upward mobility, these women have much in common with the nannies and domestic workers who arrive in Canada in the present day. In fact, one of the main requirements of the garment recruits is identical to that of an applicant for a more recent program, Canada's Live-In Caregiver Program, or LCP: they both require a 2-year contract with an employer upon arrival in the country ("Live-In Caregiver Program: Extending your stay," n.d.). Therefore, one of the main recommendations outlined in the following section can also be applied to those who come under such programs as the LCP.

\subsection{Recommendations for Further Research}

From this research, a number of topics for further study emerged. As this project is limited to the demographic of the sample, it cannot offer insight into the effects of the women's migration on their families, both the ones they left behind in the Philippines and the ones that they established in Canada. Therefore, conducting further research on the consequences of their migration on their family networks has the potential to provide a wider range of perspective on this topic.

There is also potential for further research concerning the lack of complaints of unfair treatment, and subsequently, mobilization and organization among the Filipina women during their time in the garment industry. It would be noteworthy to analyze how the socio-economic background of the women as well as the politics of the Philippines in those years might have contributed to the limited number of complaints from the interview participants, and the absence of reports of any protest activity. This finding contradicts pre-existing sources on Filipina 
garment workers (Buduhan 1972; "From Manila to Manitoba"), as well as garment workers from other ethno-cultural groups (Frager 1992; Frager \& Patrias 2005; Gannage 1986; Lepp, Millar \& Roberts 1987), which document their mobilization efforts against working conditions that were, and continue to be, notorious in the garment trade.

While the women who participated in this study may have been exploited as cheap labour, in terms of their place in the Canadian economy and in comparison to wages and working conditions of most Canadian workers, from their own personal perspective, they were improving their livelihoods. They were also grateful for the opportunity, provided to them by the Manitoban and Canadian governments. This mindset of gratitude has also been documented among Filipino domestics and nannies, who are thankful to their employers, and to Canada, for giving them a chance to leave their impoverished lives in the Philippines and earn a living in an industrialized nation, and therefore, help their family members back at home (Velasco 162). However, just because many of the women believe that they were given an opportunity, and therefore, do not view themselves as being exploited, it does not mean that, in an objective sense, there was no exploitation. Outreach and education among such workers is required, in order for them to understand that they are being allowed entry into Canada as a cheap labour force, and not because the Canadian government is offering them assistance (Velasco 162). Only then will the workers themselves realize the need to push for improved working conditions and better wages.

While this major research paper covers a topic in Canadian history that has previously been under-documented, the interviews conducted for this study, and the findings garnered from them, are merely stepping stones for subsequent inquiry. The narratives offer a rich and telling look into the working lives of the garment industry recruits who participated in the research, and 
the motivations behind both their desire to work and their willingness to take on jobs that Canadians themselves would not. Ultimately, further research and analysis must be completed in order to gain a fuller understanding of the overall working experiences of Filipina garment workers, and how their experiences can be used to improve the working conditions of immigrant women performing such gendered work in the present day. It is hoped that this paper leads to tangible steps in that direction. 


\section{Appendix A}

\section{Telephone Script}

NOTE: This script will be used if and when an interview subject expresses some interest in participating in the pilot study.

Hello _. I'm glad to hear that you're interested in learning more about my research on garment workers in Winnipeg for my major research project with Ryerson University. Can I give you more background information of my study?

This study will set out to learn more about the working experiences and conditions of Filipina garment workers who moved to Winnipeg from the Philippines in the 1960s and 1970s. I'm interested in documenting your experiences in moving to Canada, why you decided to migrate, and about the work you did when you moved to Winnipeg.

If you agree to participate, you'll help provide more in-depth knowledge of being a Filipina garment worker recruit in the time period I mentioned above.

I will be the primary researcher and interviewer. I will be recruiting 10 women to participate in 1-2 hour interviews. I will begin recruiting at the beginning of May 2012 and ideally start interviewing mid-May and finish by the month's end. After that, I will spend time preparing a final report, which I should complete by the end of August.

I'm not sure if you are taking notes, but don't worry, I'll send you all of these details after we are finished talking. Is e-mail a good way to share documents with you? [If not, ask for alternatives.]

As mentioned, I will be producing a written report that will include unattributed quotes from our interview. To be clear, your confidentiality will be maintained. Also, if you decide to participate, you will have the authority to refrain from answering any questions you're not comfortable with, or you can stop the interview altogether at any time. You will receive a copy of the final report.

I know I've just shared a lot of information. Was anything unclear? Is there anything you would like me to go over again?

I really appreciate you considering this request. If you are still interested, I will send you a Consent Form that summarizes the project and outlines the risks and benefits of participation.

After that, it's up to you. If you would like to participate, please sign one copy of the Consent Form and return it to me in the envelope provided. If you would prefer not to participate, just give me a call or send me an e-mail and let me know. I will fully respect your decision.

Please feel free to contact me with any questions or concerns. I can be reached by email at shirley.camia@ryerson.ca

Thanks again for taking the time to consider this project. I look forward to hearing from you! 


\section{Appendix B}

\section{Ryerson University \\ Consent Agreement}

\section{Stitching History: The Migration of Filipina Garment Workers to Winnipeg}

You are being asked to participate in a research study to fulfill the requirements of a Major Research Paper (MRP) for the Masters program in Immigration and Settlement Studies at Ryerson University. Before you give your consent to be a volunteer, it is important that you read the following information and ask as many questions as necessary to be sure you understand what you will be asked to do.

\section{Investigators:}

Shirley Camia, MA Student, Immigration and Settlement Studies, Ryerson University Sedef Arat-Koc, Research Supervisor, Professor, Ryerson University

\section{Purpose of the Study:}

This study will set out to examine the working experiences of Filipino women who moved to Winnipeg as garment workers in the 1960s and 1970s.

\section{Description of the Study:}

If you agree to participate, you will be asked about your living conditions in the Philippines (i.e. What work did you do in the Philippines before coming to Canada?), how you came to Canada (i.e. How were you recruited to become a garment worker in Winnipeg?), and what your working conditions were like as a garment worker (i.e. What did you do on a daily basis as a garment worker?).

The study will consist of one-on-one interviews with 10 Filipino women who arrived in Winnipeg to work as garment workers during the 1960s and 1970s. The interviews, which will last 1-2 hours, will be recorded with a tape recorder and notes will be taken.

\section{What is Experimental in this Study:}

None of the procedures used in this study are experimental in nature. The only experimental aspect of this study is the gathering of information for the purpose of analysis.

\section{Potential Risks or Discomforts:}

There is minimal risk of emotional upset in remembering events in the past, but remember that your participation in this interview is voluntary and you can choose to refrain from answering a question or stop the interview altogether at any time. 


\title{
Potential Benefits:
}

If you agree to participate, you will be part of Canadian history that has not been well documented previously.

\section{Confidentiality:}

Your confidentiality will be maintained. The recordings used to record information will only be accessed by myself and my research supervisor. The raw data collected will be stored securely at Ryerson University for a period of 6 months after the completion of this project, then it will be erased. You will be able to review and edit your recording prior to any publication. If direct quotations are used in the Major Research Paper, they will not have any identifying information or names associated with them.

\section{Voluntary Nature of Participation:}

Participation in this study is voluntary. Your choice of whether or not to participate will not influence your future relations with Ryerson University. If you decide to participate, you are free to withdraw your consent and to stop your participation at any time without penalty or loss of benefits to which you are allowed.

At any particular point in the study, you may refuse to answer any particular question or stop participation altogether.

\section{Questions about the Study:}

If you have any questions about the research now, please ask. If you have questions later about the research, you may contact:

\author{
Shirley Camia \\ Email: shirley.camia@,ryerson.ca \\ Sedef Arat-Koc \\ Email: saratkoc@politics.ryerson.ca \\ Phone: (416) 979-5000 X7338
}

If you have questions regarding your rights as a human subject and participant in this study, you may contact the Ryerson University Research Ethics Board for information.

Research Ethics Board c/o Office of the Vice President, Research and Innovation Ryerson University 350 Victoria Street

Toronto, ON M5B 2K3

Phone: (416) 979-5042 


\section{Agreement:}

Your signature below indicates that you have read the information in this agreement and have had a chance to ask any questions you have about the study. Your signature also indicates that you agree to be in the study and have been told that you can change your mind and withdraw your consent to participate at any time. You have been given a copy of this agreement.

You have been told that by signing this consent agreement you are not giving up any of your legal rights.

Participant Name (please print)

Participant Signature

Date

Investigator Signature

Date

Audio Taping Consent:

Your signature below indicates that you agree to have your interview audio taped for the research.

Participant Name (please print)

Participant Signature

Date

Investigator Signature

Date 


\section{Appendix C}

\section{Interview Questions*}

\section{LIFE IN THE PHILIPPINES AND MIGRATION TO CANADA}

Describe your life in the Philippines - How old were you when you left? What job(s) did you

have? Who did you have to support? How hard was it to make a living?

What formal education did you receive in the Philippines?

How did you learn to sew?

How did you find out about the potential to migrate to Canada?

Why did you want to go to Winnipeg?

What were your thoughts on leaving the Philippines? About moving to Winnipeg?

\section{LIFE IN WINNIPEG}

What did you know about Winnipeg before you arrived?

What first went through your mind when you arrived in Winnipeg?

How hard was it to get used to living in Winnipeg? What did you find most difficult?

What support networks did you have?

\section{WORK}

How did you decide to be a garment worker?

Who recruited you? How did they recruit you? Did you have to demonstrate any sewing skills?

Who/what company did you work for?

What was the job like? What specifically did you do?

How much did you get paid? What did you do with that money? 
What were working conditions like?

What were your hours like? Were you expected to work overtime? Did you get paid overtime pay? Why or why not?

How were you treated by your employer? Do you think you were treated fairly?

What did you do if you felt your employer was unfair?

How did the supervisors treat you at work?

How were you treated by co-workers?

How hard was the job?

What did you find the most difficult aspect of your work?

How did you deal with it? Did you have friends who were supportive?

Did you stay with your first job? Why or why not? If not - where did you go? How did you find out about that?

Is there anything else you would like to add?

*interviews will take place May 2012 


\section{Appendix D}

\section{Interview Summary}

\begin{tabular}{|c|c|c|c|c|c|}
\hline $\begin{array}{l}\text { Participant } \\
\text { (Date of } \\
\text { Interview) }\end{array}$ & $\begin{array}{c}\text { Education } \\
\text { (Level } \\
\text { Completed) }\end{array}$ & $\begin{array}{c}\text { Year of } \\
\text { Arrival in } \\
\text { Winnipeg }\end{array}$ & $\begin{array}{l}\text { Position in } \\
\text { the Garment } \\
\text { Industry }\end{array}$ & $\begin{array}{l}\text { Stayed in the } \\
\text { Industry }\end{array}$ & Treatment \\
\hline $\begin{array}{c}\text { A } \\
\text { (May 25, 2012) }\end{array}$ & Grade 7 & 1972 & $\begin{array}{l}\text { Sewing } \\
\text { Machine } \\
\text { Operator }\end{array}$ & $\begin{array}{l}\text { Yes: moved from } \\
\text { factory to factory } \\
\text { until the work slowed } \\
\text { down; eventually } \\
\text { took another job } \\
\text { assembling } \\
\text { electronic parts }\end{array}$ & Treated fairly \\
\hline $\begin{array}{c}\text { B } \\
\text { (May 25, 2012) }\end{array}$ & High School & 1969 & $\begin{array}{l}\text { Sewing } \\
\text { Machine } \\
\text { Operator; } \\
\text { became } \\
\text { Supervisor }\end{array}$ & $\begin{array}{l}\text { Yes: moved to a few } \\
\text { factories before } \\
\text { staying at Tan Jay } \\
\text { until retirement; also } \\
\text { worked in a nursing } \\
\text { home for a while }\end{array}$ & Treated fairly \\
\hline$\frac{C}{\text { (May 26, 2012) }}$ & Grade 6 & 1971 & $\begin{array}{l}\text { Sewing } \\
\text { Machine } \\
\text { Operator }\end{array}$ & $\begin{array}{l}\text { Yes; moved from } \\
\text { factory to factory } \\
\text { until the work } \\
\text { slowed; eventually } \\
\text { took another job with } \\
\text { a company making } \\
\text { kitchen cabinets }\end{array}$ & Treated fairly \\
\hline $\begin{array}{c}\text { D } \\
\text { (May 28, 2012) }\end{array}$ & High School & 1974 & $\begin{array}{l}\text { Sewing } \\
\text { Machine } \\
\text { Operator }\end{array}$ & $\begin{array}{l}\text { No: moved to health } \\
\text { care because friends } \\
\text { had said that the } \\
\text { garment industry was } \\
\text { slowing down }\end{array}$ & $\begin{array}{l}\text { Treated fairly; recalls } \\
\text { only getting in trouble } \\
\text { once, when a } \\
\text { colleague was } \\
\text { making her laugh; } \\
\text { they both got in } \\
\text { trouble for being } \\
\text { loud; also recalls } \\
\text { Filipinos being called } \\
\text { mosquitoes by other } \\
\text { co-workers, but she } \\
\text { didn't care }\end{array}$ \\
\hline
\end{tabular}




\begin{tabular}{|c|c|c|c|c|c|}
\hline $\begin{array}{l}\text { Participant } \\
\text { (Date of } \\
\text { Interview) }\end{array}$ & $\begin{array}{l}\text { Education } \\
\text { (Level } \\
\text { Completed) }\end{array}$ & $\begin{array}{l}\text { Year of } \\
\text { Arrival in } \\
\text { Winnipeg }\end{array}$ & $\begin{array}{l}\text { Position in } \\
\text { the Garment } \\
\text { Industry }\end{array}$ & $\begin{array}{l}\text { Stayed in the } \\
\text { Industry }\end{array}$ & Treatment \\
\hline $\begin{array}{c}E \\
\text { (May 28, 2012) }\end{array}$ & Grade 6 & 1968 & $\begin{array}{l}\text { Sewing } \\
\text { Machine } \\
\text { Operator; } \\
\text { became } \\
\text { Supervisor }\end{array}$ & $\begin{array}{l}\text { Yes and No: left after } \\
2 \text { years to work at a } \\
\text { restaurant to improve } \\
\text { her English; took on } \\
\text { other work before } \\
\text { returning to the } \\
\text { garment industry as a } \\
\text { Supervisor; left when } \\
\text { work slowed and } \\
\text { entered health care } \\
\text { sector }\end{array}$ & $\begin{array}{l}\text { Felt tension among } \\
\text { other colleagues at } \\
\text { first, but it got better } \\
\text { when they got to } \\
\text { know each other } \\
\text { better; recalls being } \\
\text { given a hard time by } \\
\text { other Filipinos as a } \\
\text { Supervisor; was fired } \\
\text { after a run-in with } \\
\text { someone she was } \\
\text { training, also Filipino }\end{array}$ \\
\hline $\begin{array}{c}F \\
\text { (May 29, 2012) }\end{array}$ & $\begin{array}{c}\text { Some } \\
\text { University } \\
\text { (took } \\
\text { Science and } \\
\text { Commerce) }\end{array}$ & 1968 & $\begin{array}{l}\text { Sewing } \\
\text { Machine } \\
\text { Operator }\end{array}$ & $\begin{array}{l}\text { No: left after } 2 \text { years; } \\
\text { did other work, } \\
\text { mostly retail and } \\
\text { entrepreneurial work } \\
\text { with her husband; } \\
\text { viewed the } \\
\text { opportunity to come } \\
\text { to Canada as a } \\
\text { garment worker as a } \\
\text { stepping stone }\end{array}$ & $\begin{array}{l}\text { Recalls racism from } \\
\text { other workers who } \\
\text { were also immigrants }\end{array}$ \\
\hline $\begin{array}{c}G \\
\text { (May 30, 2012) }\end{array}$ & High School & 1968 & $\begin{array}{l}\text { Sewing } \\
\text { Machine } \\
\text { Operator }\end{array}$ & $\begin{array}{c}\text { No: left to work with } \\
\text { a company that } \\
\text { made buses (higher } \\
\text { pay) }\end{array}$ & Treated fairly \\
\hline $\begin{array}{c}\text { H } \\
\text { (May 30, 2012) }\end{array}$ & $\begin{array}{l}\text { Some } \\
\text { University } \\
\text { (took } \\
\text { Education) }\end{array}$ & 1969 & $\begin{array}{l}\text { Sewing } \\
\text { Machine } \\
\text { Operator; } \\
\text { became } \\
\text { Supervisor }\end{array}$ & $\begin{array}{c}\text { No: after a number of } \\
\text { years, eventually left } \\
\text { to work as a health } \\
\text { care aide }\end{array}$ & $\begin{array}{l}\text { Says she was treated } \\
\text { fairly; over worked - } \\
\text { worked 7am-10pm } \\
\text { shifts as a Supervisor } \\
\text { because her boss } \\
\text { didn't trust anyone } \\
\text { else; treated rudely at } \\
\text { times by other } \\
\text { Filipinos as a } \\
\text { Supervisor, and the } \\
\text { Plant Manager, who } \\
\text { she says was rude to } \\
\text { everyone }\end{array}$ \\
\hline
\end{tabular}




\section{Reference List}

Archer, K. \& Berdahl, L. (2011). Explorations: Conducting Empirical Research in Canadian Political Science. Don Mills, ON: Oxford University Press.

Bannerji, H. (1998). On the Dark Side of the Nation: Politics of Multiculturalism and the State of 'Canada.' In C. Verduyn (Ed.), Literary Pluralities (pp. 125-151). Peterborough, ON: Broadview Press.

Bejar, J. (2006). Transnational communities: Filipina nurses in rural Manitoba, 1965-1970 (Master's major research project). Ryerson University, Toronto, Ontario.

Belvez, P.M. (n.d.). Development of Filipino, The National Language of the Philippines/ National Commission for Culture and the Arts. Retrieved from: http://www.ncca.gov.ph/about-culture-and-arts/articles-on-c-n-a/article.php? igm $=3 \& \mathrm{i}=207$

Buduhan, C. (1972). An Urban Village: The Effects of Migration on the Filipino Garment Workers in a Canadian City (Master's thesis). University of Manitoba, Winnipeg, Manitoba.

Citizenship and Immigration Canada. Live-in caregiver program: extending your stay (n.d.). Retrieved from Citizenship and Immigration Canada website: http://www.cic.gc.ca/english/work/caregiver/extend-stay.asp

Dalayoan, F. (Producer \& Director). (2012). Manila Road [Documentary]. Canada: Blue Water Buffalo Productions.

Frager, R. A. (1992). Sweatshop Strife: Class, Ethnicity, and Gender in the Jewish Labour Movement of Toronto 1900-1939. Toronto: University of Toronto Press.

Frager, R. A., \& Patrias, C. (2005). Discounted Labour: Women Workers in Canada, 1870-1939. Toronto: University of Toronto Press. 
"From Manila to Manitoba" Exhibit. (2010). The Manitoba Museum. 190 Rupert Avenue Winnipeg, Manitoba R3B 0N2.

Galabuzi, G. (2006). Canada's Economic Apartheid: The Social Exclusion of Racialized Groups in the New Century. Toronto: Canadian Scholars' Press.

Gannage, C. (1986). Double Day Double Bind: Women Garment Workers. Toronto: Women's Press.

Giesbrecht, J. (2010). Accommodating Resistance: Unionization, Gender, and Ethnicity in Winnipeg's Garment Industry, 1929-1945. Urban History Review, XXXVIX(1), 5-19.

Gupta, T.D. (1996). Racism and Paid Work. Toronto: Broadview Press.

Kelley, N., \& Trebilcock, M. (1998). The Making of the Mosaic: A History of Canadian Immigration Policy. Toronto: University of Toronto Press.

Khatun, A. (2005). Worker Views on Changes in the Winnipeg Garment Industry: In-depth Interviews with Ten Immigrant Garment Workers. In R. Wiest (Ed.), The Winnipeg Garment Industry: Development and Employment (pp. 67-102). Winnipeg: Manitoba Research Alliance.

Laquian, E.R. (1973). A Study of Filipino Immigration to Canada, 1962-1972. Ottawa: United Council of Filipino Associations in Canada.

Lepp, A., Millar, D., \& Roberts, B. (1987). Women in the Winnipeg Garment Industry, 1950s-1970s. In M. Kinnear (Ed.), First Days, Fighting Days: Women in Manitoba History (pp. 149-172). Regina: Canadian Plains Research Centre, University of Regina.

Lett, D. (2012, March 3). Filipinos Transform Manitoba. Winnipeg Free Press. Retrieved from: http://www.winnipegfreepress.com 
Litta-Magnus, C. (1969, June 28). Garment Workers Arrive: 40 Filipino Women Welcomed at Airport. Winnipeg Free Press.

Political economy analysis. (n.d.). Retrieved from Organisation and Economic Co-operation Development (OECD) website:

http://www.oecd.org/document/8/0,3746,en_2649_34565_37957768_1_1_1_1,00.html

Velasco, P. M. (1997). 'We Can Still Fight Back': Organizing Domestic Workers in Toronto. In A. Bakan \& D. Stasiulis (Eds.), Not one of the Family: Foreign Domestic Workers in Canada (pp. 157-164). Toronto: University of Toronto Press.

Wiley, J. (1981, May 28). Salary differential based on sex bias, striking garment workers charge. Winnipeg Free Press. 